\title{
7.3 \\ La Financiación de las Empresas Agrarias
}

\author{
D. Carlos Osés Irulegui \\ Jefe de Administración y Control de C.R.V.
}

\begin{abstract}
Sumario: 1. Estructura del sistema agroalimentario: 1.0. Introducción. 1.1. Importancia y evolución del Sistema Agroalimentario en la economía vasca. 1.2. Evolución Sectorial del Personal Ocupado. 1.3. Estructura Sectorial y Evolución del Sistema Agroalimentario. 1.4. Estructura Territorial y Evolución del Sistema Agroalimentario. 1.5. Situación del Asociacionismo Agrario. 1.6. Situación del Sistema Agroalimentario en Ipar Kutxa - Caja Rural Vasca.-2. Financiación de la empresa agraria: A. Estructura patrimonial. A.0. Introducción. A.1. Equilibrio entre Financiación a Corto - Largo Plazo. A.2. Equilibrio en las Fuentes de Financiación: Fondos Propios - Financiación Ajena. A.3. Comparativa Estructura Industrias Agroalimentarias. B. Fórmulas de financiación. B.1. Fondos Propios. B.1.1. Participación Directa. B.1.2. Sociedades de Capital Riesgo (Participación Indirecta). B.1.3. Autofinanciación. B.1.4. Recursos Propios mediante acceso al Mercado Bursátil. B.2. Financiación Pública - Subvenciones. B.2.0. Introducción. B.2.1. Criterios y Ayudas Comunitarias. B.2.2. Criterios y Ayudas CAV. B.2.3. Entidades de Apoyo al Sector Agroalimentario. B.3. Financiación Ajena a Largo Plazo. B.3.1. Sociedades de Garantía Recíproca (S.G.R.). B.3.2. Crédito o Préstamo Hipotecario. B.3.3. Leasing. B.3.4. Créditos Sindicados. B.3.5. Mercados Financieros. B.4. Financiación Ajena a Corto Plazo. B.4.1. Descuento de efectos. B.4.2. Póliza o Cuenta de Crédito a la vista. B.4.3. Otras formas de financiación a Corto Plazo. B.4.3.1. Anticipos de Crédito. B.4.3.2. «Factoring». B.4.3.3. «Confirming». B.4.3.4. «Renting». B.4.3.5. «Circulante Operativo».
\end{abstract}

\section{ESTRUCTURA DEL SISTEMA AGROALIMENTARIO}

\subsection{Introducción}

En primer lugar, considero necesario acercarnos a las principales magnitudes y evolución de lo que podríamos calificar como Sistema Agroalimentario Vasco.

El sistema Agroalimentario comprende dos tipos de actividades: 
- Actividades Productivas o Extractiva Primaria, con los siguientes «Sectores Primarios»:

- Sector Agrario: agricultura, ganadería y forestal.

- Sector Pesquero.

-Industria Agroalimentaria: correspondiente a aquellas actividades industriales que se ocupan de la transformación de la producción «primaria» con fines de alimentación.

En la aproximación a la realidad económica del Sistema Agroalimentario, donde nos centraremos básicamente en la Comunidad Autónoma Vasca tanto por la coherencia en los datos estadísticos disponibles como por ser el ámbito de implantación actual de la Caja, es imprescindible remarcar que la valoración económica, reflejada contablemente en las estadísticas tradicionales, de lo que representa el Sistema Agroalimentario Vasco no refleja su verdadera importancia en términos socioeconómicos al no valorar otras funciones de carácter implícito en la actividad agraria como el papel que el Sector Primario juega en el mantenimiento de un medio rural, y un entorno natural en equilibrio, como la garantía para el consumidor en sus alimentos, mantenimiento de una población ligada a la tierra que impide un despoblamiento de zonas distintas a los núcleos urbanos, funciones de carácter cultural, o incluso aspectos intangibles como la imagen de productos de calidad como el vino de Rioja Alavesa, en el exterior.

\subsection{Importancia y evolución del Sistema Agroalimentario en el marco de la economía vasca}

\section{Sector Primario}

La aportación del Sector Primario ha pasado de representar algo más de un 2,9\% del VAB p.m. en 1980 a poco más del $1 \%$, el 1,02\% en el 2001 con un volumen de 390 millones de euros.

Se puede concluir que partiendo de una escasa participación en la economía vasca, su peso relativo va disminuyendo contrastando su estancamiento con el dinamismo del resto de sectores, sobro todo Construcción y Servicios con crecimientos en el periodo 1980-2001, en volumen, en torno al $700 \%$, aún cuando debemos ser conscientes que al hablar del Sector Agrario y Pesquero nos referimos a las tres cuartas partes del territorio de la C.A.V. y a los habitantes de sus pueblos, en su mayoría unidos de una u otra forma al trabajo en la tierra y en el mar. 
Valor Añadido Bruto p.m. C.A.V. Precios Corrientes.
Distribución porcentual respecto al total

\begin{tabular}{|c|c|c|c|c|c|c|c|c|}
\hline \multirow{2}{*}{ Sectores } & \multirow{2}{*}{1980} & \multirow{2}{*}{1985} & \multirow{2}{*}{1990} & \multirow{2}{*}{1995} & \multirow{2}{*}{2000} & \multicolumn{2}{|c|}{$2001 \mathrm{~A}$} & \multirow{2}{*}{$\begin{array}{c}1980-2001 \\
\% \text { Var. Importe }\end{array}$} \\
\hline & & & & & & $\%$ & Importe & \\
\hline $\begin{array}{l}\text { Agricultura/Pesca } \\
\text { Industria } \\
\text { Construcción } \\
\text { Servicios }\end{array}$ & $\begin{array}{r}2,91 \% \\
50,19 \% \\
5,16 \% \\
41,73 \%\end{array}$ & $\begin{array}{r}2,50 \% \\
46,38 \% \\
5,83 \% \\
45,29 \%\end{array}$ & $\begin{array}{r}2,39 \% \\
41,87 \% \\
6,97 \% \\
48,77 \%\end{array}$ & $\begin{array}{r}1,57 \% \\
36,07 \% \\
7,33 \% \\
55,03 \%\end{array}$ & $\begin{array}{r}1,21 \% \\
36,58 \% \\
7,10 \% \\
55,11 \%\end{array}$ & $\begin{array}{r}1,02 \% \\
36,04 \% \\
7,48 \% \\
55,46 \%\end{array}$ & $\begin{array}{r}390 \\
13.845 \\
2.871 \\
21.308\end{array}$ & $\begin{array}{l}103 \% \\
319 \% \\
746 \% \\
676 \%\end{array}$ \\
\hline Total & $100 \%$ & $100 \%$ & $100 \%$ & $100 \%$ & $100 \%$ & $100 \%$ & 38.410 & $484 \%$ \\
\hline
\end{tabular}

(A) Avance: importe en millones de euros.

Fuente: Eustat. Cuentas Económicas.

NотA: V.A.B. - P.I.B. - Imptos ligados a Importación - IVA.

\begin{tabular}{|l|c|}
\hline \multicolumn{1}{|c|}{ Países } & $\begin{array}{c}\text { \% Participación } \\
\text { Agricultura } \\
\text { s/ PIB }\end{array}$ \\
\hline Unión Europea & 1,7 \\
Bélgica & 1,1 \\
Dinamarca & 2 \\
Alemania & 0,9 \\
Grecia & 6,8 \\
España & 3,7 \\
Francia & 2,3 \\
Irlanda & 2,6 \\
Italia & 2,4 \\
Luxemburgo & 0,6 \\
Holanda & 2,2 \\
Austria & 1,2 \\
Portugal & 2,4 \\
Finlandia & 0,9 \\
Suecia & 0,7 \\
Reino Unido & 0,7 \\
\hline
\end{tabular}

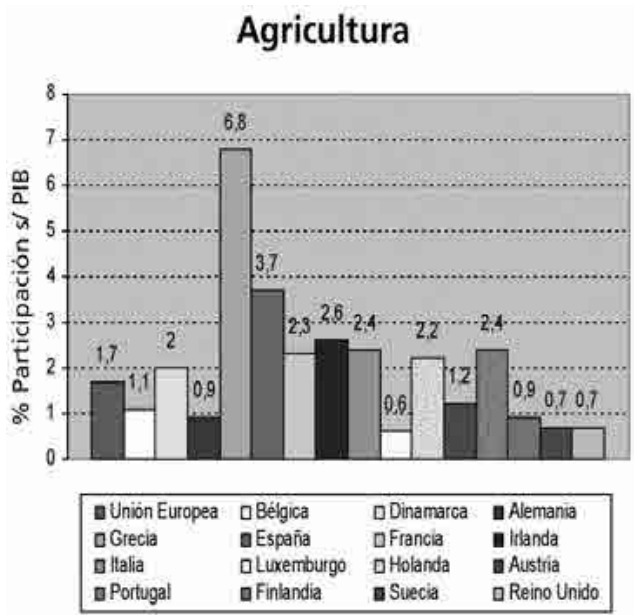

Fuente: European Commission (Eurostat and Directorate - General for Agriculture), FAO and UNSO.

Las explotaciones agrícolas están muy condicionadas por las características geográficas, climatológicas y sociales, teniendo por tanto una importancia desigual, en cuanto a su aportación al PIB, tanto 
dentro del Estado español, como entre los diferentes países comunitarios.

Industria Agroalimentaria

Valor Añadido Bruto (Salida Fábrica). Precios Corrientes

\begin{tabular}{|l|c|c|c|}
\hline & 1995 & 1998 & 2000 \\
\hline Industria Agroalimentaria & 6,20 & 6,11 & 5,67 \\
Resto Industrias & 93,80 & 93,89 & 94,33 \\
\hline Total Industrias & 100 & 100 & 100 \\
\hline \%Industria Agroalimentaria sNAB p.m. C.A.V. & 2,24 & 2,25 & 2,07 \\
\hline
\end{tabular}

Fuente: Eustat Cuentas Industriales CAV.

NotA: Sin incluir el subsector de la Transformación de la Madera.

Completando el análisis del Sector Primario con el factor transformador, éste concentra en torno al $6 \%$ (con leve tendencia decreciente) de la riqueza que obtiene la industria total por lo que su aportación al VAB se cuantifica en dos puntos de la economía vasca, duplicando la aportación del Sector Primario y situando la importación del Sistema Agroalimentario Vasco en torno al 3 \% de la economía.

Es muy importante la implicación de la transformación y comercialización en la cadena de valor de la producción agraria, favoreciendo la aparición de nuevas iniciativas económicas y proyectos de desarrollo endógeno en las zonas rurales, lo que sin duda contribuye a la diversificación de su tejido productivo.

\subsection{Evolución Sectorial del personal ocupado}

Sector Primario

El Sector Primario Vasco da empleo al 1,7\% de la población según los datos del 2001 elaborados por Eustat, disminuyendo su participación desde el 5 \% en 1985.

Los casi 200.000 empleos netos creados en el periodo, el $95 \%$ han sido absorbidos por el Sector Servicios, habiendo perdido el Sector Primario 18.000 empleos en el periodo analizado. 
Población de 16 y más años ocupada según el sector económico (en miles)

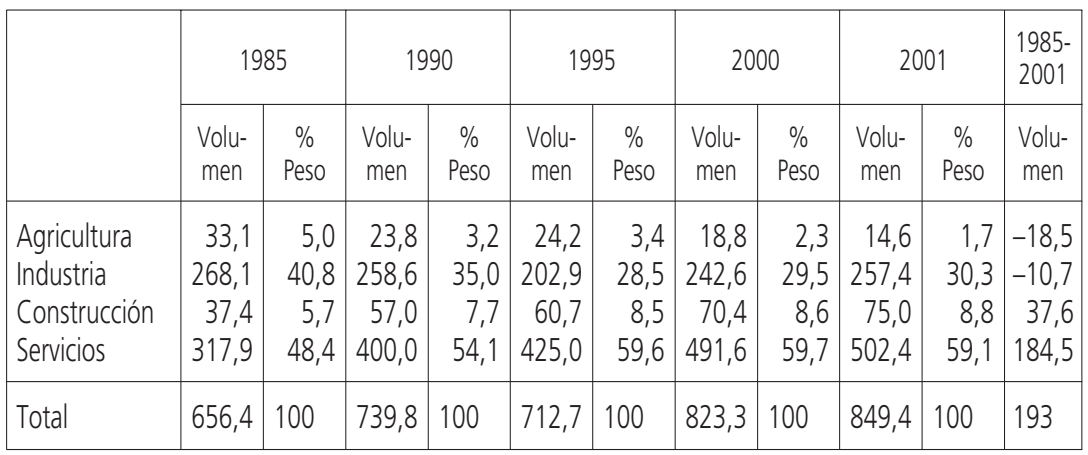

Fuente: Eustat - Encuesta de Población en Relación con la Actividad.
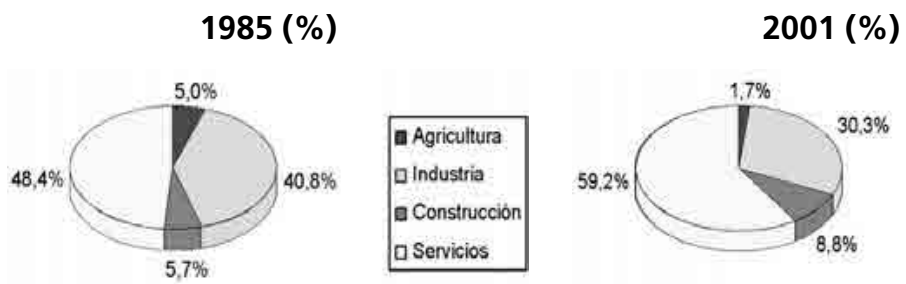

agricultura
$\square$ Industria
a Construccion
$\square$ Servicios

\section{Distribución de la diferencia}

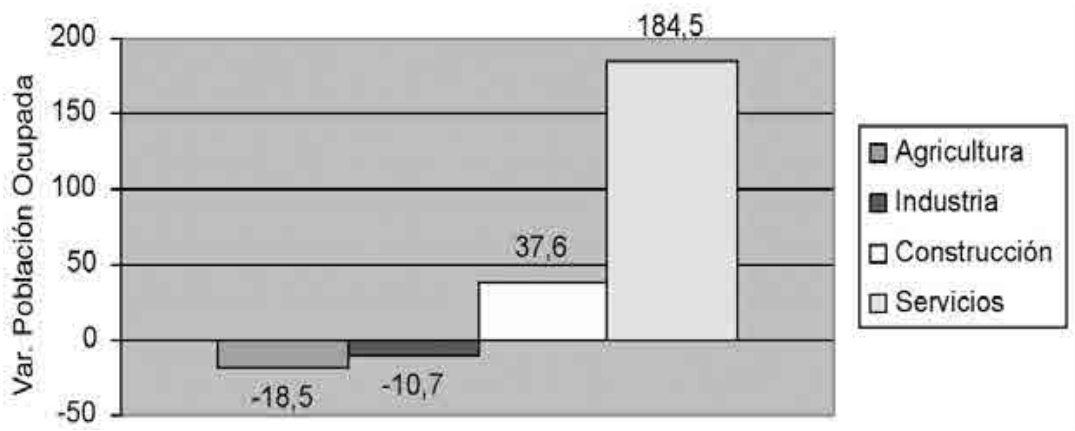


Industria Agroalimentaria

\begin{tabular}{|l|r|r|r|c|}
\hline & 1995 & 1998 & 2000 & $2000-1995$ \\
\hline Industria Agroalimentaria & $5,1 \%$ & $4,8 \%$ & $4,8 \%$ & $17,8 \%$ \\
Resto Industria & $94,9 \%$ & $95,2 \%$ & $95,2 \%$ & \\
\hline Total Industria & $100 \%$ & $100 \%$ & $100 \%$ & $23,2 \%$ \\
\hline \%Industria Agroalimentaria s/Empleo CAV & $1,5 \%$ & $1,4 \%$ & $1,4 \%$ & \\
\hline
\end{tabular}

Fuente: Eustat - Cuentas Industriales.

Respecto a la Industria Agroalimentaria la población ocupada se sitúa de forma estable en torno al $5 \%$ del total de la industria, con un crecimiento del empleo del $18 \%$ en el periodo 1995-2000, ligeramente inferior al total del Sector Industrial. De esta forma el total del Sistema Agroalimentario Vasco emplea en torno al $3 \%$ en la CAV, cifra similar al peso económico del sector.

\section{Conclusión}

Como observamos, es el Sector Primario el que fundamentalmente va viendo reducida su participación en la economía vasca, tanto en términos de VAB como de empleo, pero no obstante, la renta media por ocupado en el Sector Primario es la que más ha crecido en el periodo $1985-2001$ (200\% frente a $162 \%, 107 \%$ y $100 \%$ del resto de sectores) por lo que estos datos nos hablan de un sector que a pesar de perder implantación socioeconómica, siendo apoyo económico de un menor número de personas, está creciendo en rentabilidad de sus explotaciones, creando la capacidad de que aquellos que desarrollan esta actividad pueden efectivamente vivir de ella, con ratios productivos y sanitarios de los más elevados del Estado y cercanos a los de las grandes potencias agrarias de la Unión Europea.

\subsection{Estructura Sectorial y Evolución del Sistema Agroalimentario}

Hasta ahora hemos considerado el Sector Primario y su Industria Transformadora como algo uniforme, pero sus diferentes subsectores presentan situaciones totalmente diferentes. 
Sector Primario

Producción Final Agraria

\begin{tabular}{|l|r|r|r|r|c|c|}
\hline \multirow{2}{*}{ Subsector } & \multirow{2}{*}{1995} & \multirow{2}{*}{1997} & \multicolumn{2}{c|}{2000} & \multicolumn{2}{c|}{$2000-1995$} \\
\cline { 4 - 7 } & & & $\%$ & Importe (*) & Importe $\left.{ }^{*}\right)$ & $\%$ \\
\hline Agrícola & $34,8 \%$ & $38,7 \%$ & $52,2 \%$ & 281 & 120 & $74 \%$ \\
Ganadero & $40,9 \%$ & $35,7 \%$ & $29,9 \%$ & 161 & -29 & $-15,3 \%$ \\
Forestal & $20,9 \%$ & $22,8 \%$ & $15,1 \%$ & 81 & -16 & $-16,1 \%$ \\
Otros & $3,4 \%$ & $2,9 \%$ & $2,9 \%$ & 15 & - & - \\
\hline Total Sector Agrario & $100 \%$ & $100 \%$ & $100 \%$ & 538 & 75 & $16,1 \%$ \\
\hline
\end{tabular}

${ }^{*}$ ) Importe en millones de euros.

Fuente: Eustat - Cuentas Económicas.

(NotA: VAB p.m. = Producción Final Agraria - Gastos Fuera Sector)

Respecto al Sector Agrario, es el subsector Agrícola el que más importancia tiene con el $52 \%$ de la producción final y el que mayor crecimiento ha tenido en el periodo 2000-1995 con un $74 \%$, mientras que el subsector Ganadero, que en 1995 era el más importante, ha reducido un $16 \%$, en el periodo, su participación hasta el $30 \%$ de la producción final total agraria.

SUbSECTOR Agrícola

\begin{tabular}{|l|r|r|r|c|}
\hline \multirow{2}{*}{ Producto } & \multicolumn{3}{|c|}{ Producción final } & \multirow{2}{*}{$\begin{array}{c}\text { Var. Volumen } \\
1995-2000\end{array}$} \\
\cline { 2 - 4 } & 1995 & 1997 & 2000 & \\
\hline Cereales & $15,1 \%$ & $12,1 \%$ & $9,0 \%$ & $4,1 \%$ \\
Leguminosas & $1,5 \%$ & $1,1 \%$ & $0,8 \%$ & $-3,3 \%$ \\
Tubéc. cons. humano & $9,7 \%$ & $6,1 \%$ & $3,7 \%$ & $-34,3 \%$ \\
Cultivos ind. herbáceos & $6,5 \%$ & $5,8 \%$ & $3,1 \%$ & $-15,6 \%$ \\
Hortalizas & $24,4 \%$ & $22,7 \%$ & $19,9 \%$ & $41,8 \%$ \\
Frutos & $7,2 \%$ & $5,1 \%$ & $3,9 \%$ & $-33 \%$ \\
Vinos y subproductos & $30,4 \%$ & $43,6 \%$ & $55,2 \%$ & $215,8 \%$ \\
Aceite y subproductos & $0,1 \%$ & $0,1 \%$ & $0,1 \%$ & $54,7 \%$ \\
Flores y plantas ornam. & $2,7 \%$ & $2,2 \%$ & $3,4 \%$ & $113,6 \%$ \\
Semillas selectas y plantones agrícolas & $2,5 \%$ & $1,2 \%$ & $1,0 \%$ & $-29,7 \%$ \\
\hline Total & $100,0 \%$ & $100,0 \%$ & $100,0 \%$ & $74,0 \%$ \\
\hline
\end{tabular}

Fuente: Eustat - Cuentas Económicas. 


\section{Producción Final Subsector Agrícola}

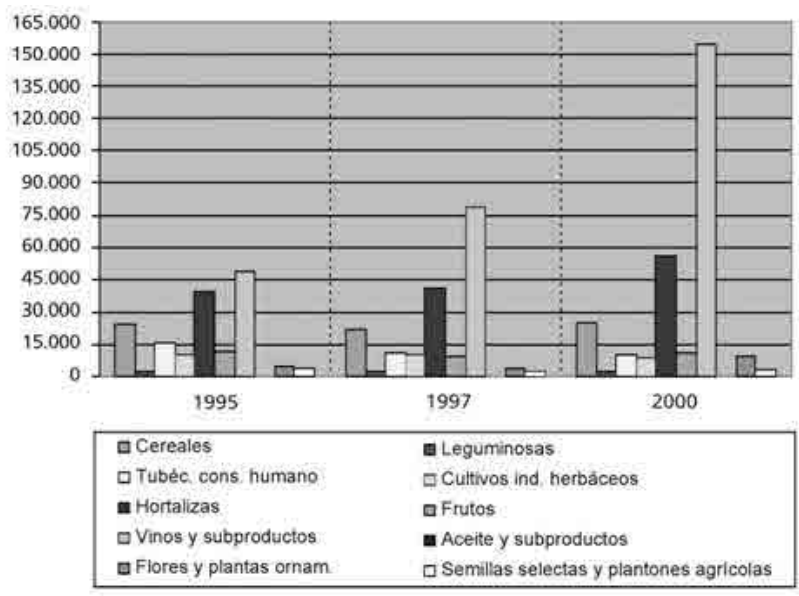

En el Subsector Agrícola son destacables los crecimientos en términos corrientes de las «Hortalizas» y «Flores y Plantas Ornamentales», siendo el producto que merece mención aparte el del Vino con ascensos del $215 \%$ en el periodo 1995-2000 hasta alcanzar los 154 millones de euros, el $55 \%$ del total Sector Agrícola.

\section{SubSECtOR GANADERO}

\begin{tabular}{|l|r|r|r|r|}
\hline \multirow{2}{*}{ Producto } & \multicolumn{3}{|c|}{ Producción final } & \multirow{2}{*}{$\begin{array}{c}\text { V Var. Volumen } \\
1995-2000\end{array}$} \\
\cline { 2 - 4 } & 1995 & 1997 & 2000 & \\
\hline Carne y ganado: Vacuno & $28,2 \%$ & $22,0 \%$ & $23,1 \%$ & $-30,7 \%$ \\
Carne de ganado: Ovino & $3,9 \%$ & $4,4 \%$ & $4,5 \%$ & $-2,7 \%$ \\
Carne de ganado: Caprino & $0,4 \%$ & $0,4 \%$ & $0,5 \%$ & $27,8 \%$ \\
Carne de ganado: Porcino & $7,2 \%$ & $6,6 \%$ & $4,4 \%$ & $-47,9 \%$ \\
Carne de ganado: Aves & $5,4 \%$ & $0,1 \%$ & $-0,8 \%$ & $-112,5 \%$ \\
Carne de ganado: Conejos & $2,1 \%$ & $3,6 \%$ & $2,6 \%$ & $4,2 \%$ \\
Carne de ganado: Equino & $0,3 \%$ & $0,4 \%$ & $0,4 \%$ & $20,5 \%$ \\
Leche & $41,2 \%$ & $49,4 \%$ & $50,6 \%$ & $4,0 \%$ \\
Huevos & $10,2 \%$ & $11,8 \%$ & $13,5 \%$ & $12,0 \%$ \\
Lana & $0,0 \%$ & $0,2 \%$ & $0,0 \%$ & $-9,3 \%$ \\
Varios & $1,0 \%$ & $1,2 \%$ & $1,0 \%$ & $-10,2 \%$ \\
\hline Total & $100,0 \%$ & $100,0 \%$ & $100,0 \%$ & $-15,3 \%$ \\
\hline
\end{tabular}

Fuente: Eustat - Cuentas Económicas 


\section{Producción Final Subsector Ganadero}

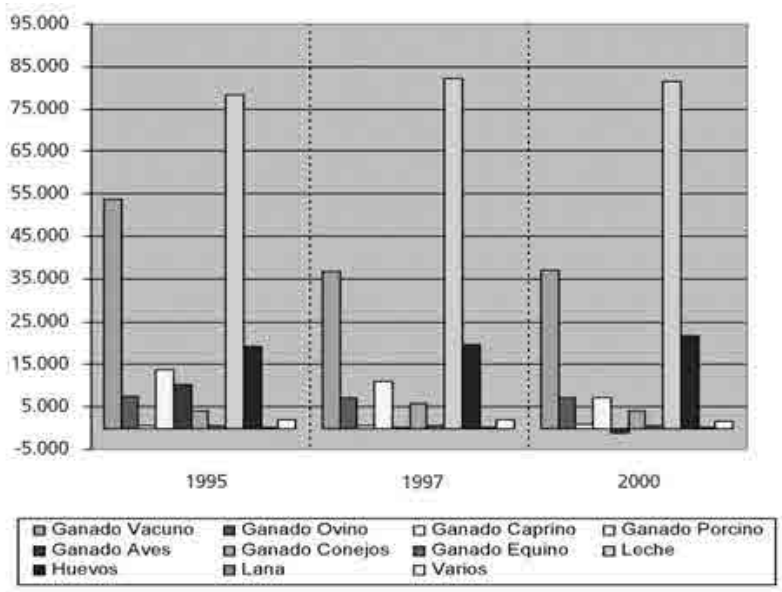

El Subsector Ganadero presenta una disminución del $15 \%$ en el periodo 1995-2000 en valores corrientes con especial incidencia de la "Carne y Ganado Vacuno», manteniéndose como producto más importante (el 50,6 \% del subsector) el de producción de «Leche».

\section{SUBSECTOR FORESTAL}

La superficie forestal se mantiene en los últimos años estable en torno a las 390.000 has. lo que supone un $54 \%$ de la superficie total. De ellas, 150.000 has. son de pino radiata, sobre el cual se asienta el sector forestal, importante generador de empleo y riqueza. El $63 \%$ de la superficie arbolada es de propiedad privada. La actividad más importante está ligada con el aserrío, transformación o trituración de la madera.

La accidentada orografía y el minifundismo forestal son algunos de los principales problemas del sector silvícola, además de los riesgos que conlleva la excesiva monoespecifidad de los bosques y ciertos métodos de aprovechamiento de algunas de las especies utilizadas. No obstante las posibilidades de desarrollo de este sector son considerables, ya que los bosques por su carácter multifuncional contribuyen a la estabilidad ecológica del entorno rural y tienen también importantes funciones socioeconómicas. 
VAB SF - Sector Pesquero

\begin{tabular}{|c|c|c|c|c|}
\hline Subsector & 1995 & 1997 & 1999 & 1999-1995 \\
\hline Bajura & $28,3 \%$ & $35,4 \%$ & $32,3 \%$ & $3,2 \%$ \\
\hline Altura & $23,8 \%$ & $23,1 \%$ & $19,9 \%$ & $-24,0 \%$ \\
\hline Bacaladeros & $5,1 \%$ & $4,8 \%$ & $6,5 \%$ & $14,8 \%$ \\
\hline Total actividad en costa & $57,2 \%$ & $63,3 \%$ & $58,7 \%$ & \\
\hline Atuneros Congeladores & $36,9 \%$ & $34,2 \%$ & $41,3 \%$ & - \\
\hline Arrastreros Congeladores & $5,9 \%$ & $2,5 \%$ & - & - \\
\hline Total Sector Pesquero & $100 \%$ & $100 \%$ & $100 \%$ & $-9,4 \%$ \\
\hline
\end{tabular}

Fuente: Eustat - Cuentas Industriales CAV.

Respecto a la actividad extractiva de la pesca, ha sufrido un retroceso del 9,4\% en el periodo 1995-1999 con reducción de la pesca de altura en un $24 \%$ hasta representar el $20 \%$ del sector y un mantenimiento de la pesca de bajura con el $32 \%$ del sector.

\section{Industria Agroalimentaria}

Los diferentes subsectores que integran el sector de Industrias Agroalimentarias tienen características estructurales y operativas muy distintas, e incluso para un mismo producto coexisten grandes empresas con tecnología avanzada junto a pequeñas empresas, incluso establecimientos artesanales. No obstante, si algo caracteriza al conjunto de las empresas agroalimentarias es precisamente su complejidad, al operar con gran variedad de materias primas y además estar muy afectadas por el carácter estacional de su materia prima, lo que requiere una gran adaptación a la evolución que se observa en sus procesos industriales y a la necesidad de importantes volúmenes financieros.

Con todo ello, podemos definir a la Industria Agroalimentaria como aquella que utiliza materias primas muy heterogéneas, procedentes del reino animal o vegetal, y que, haciendo uso de una gran variedad de procesos tecnológicos industriales, obtiene productos que se destinan fundamentalmente a la alimentación humana o animal.

De igual forma que en el Sector Primario, la industria transformadora también presenta una gran dispersión tanto en la importación de los diferentes subsectores como en la diferente evolución de los mismos. 


\begin{tabular}{|l|r|r|r|r|r|r|r|}
\hline \multirow{2}{*}{ VAB p/m. } & \multirow{2}{*}{1995} & \multirow{2}{*}{1998} & \multicolumn{3}{|c|}{2000} & \multicolumn{2}{|c|}{$1995-2000$} \\
\cline { 5 - 8 } & & & Peso & $\begin{array}{c}\text { Aportación } \\
\text { VAB }\end{array}$ & $\begin{array}{c}\text { Importe } \\
(*)\end{array}$ & $\%$ & $\begin{array}{c}\text { Importe } \\
\left({ }^{*}\right)\end{array}$ \\
\hline Industrias Cárnicas & $5,4 \%$ & $4,7 \%$ & $5,3 \%$ & $0,11 \%$ & 41 & $31,1 \%$ & 10 \\
Industrias Lácteas & $10,3 \%$ & $5,4 \%$ & $8,5 \%$ & $0,18 \%$ & 65 & $9,1 \%$ & 5 \\
Conservas de Pescado & $6,9 \%$ & $7 \%$ & $8,4 \%$ & $0,18 \%$ & 64 & $59,5 \%$ & 24 \\
Pan y Molinería & $17,7 \%$ & $17 \%$ & $17,4 \%$ & $0,36 \%$ & 132 & $29,1 \%$ & 30 \\
Otros Alimenticios & $34,6 \%$ & $35,6 \%$ & $29,9 \%$ & $0,62 \%$ & 227 & $13,5 \%$ & 27 \\
Bebidas & $25,1 \%$ & $30,4 \%$ & $30,3 \%$ & $0,63 \%$ & 230 & $58,2 \%$ & 84 \\
\hline Total Industria Agroalimentaria & $100 \%$ & $100 \%$ & $100 \%$ & 2,07 & 758 & $31,2 \%$ & 180 \\
\hline Total Industria Agroalimentaria & $6,2 \%$ & $6,1 \%$ & $5,7 \%$ & & 13.371 & $43,6 \%$ & 4.060 \\
\hline S/Total Industria & & & & & & & \\
\hline
\end{tabular}

$\left.{ }^{*}\right)$ Importe: mill. de euros.

Fuente: Eustat - Cuentas Industriales CAV.

1995

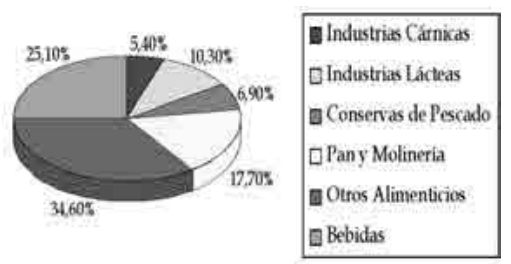

2000

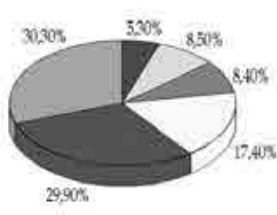

DIndustrias Camicas

$\square$ Industrias Lácteas

- Conservas de Pescado

$\square$ Pany Molinería

Otros Alimenticios

口Bebidas

\begin{tabular}{|c|c|c|c|c|c|}
\hline Variación anual & 1996 & 1997 & 1998 & 1999 & 2000 \\
\hline $\begin{array}{l}\text { Industrias Cárnicas } \\
\text { Industrias Lácteas } \\
\text { Conservas de Pescado } \\
\text { Pan y Molinería } \\
\text { Otras Alimenticias } \\
\text { Bebidas }\end{array}$ & $\begin{array}{c}-8,8 \% \\
2,7 \% \\
3,1 \% \\
-4,7 \% \\
6,6 \%\end{array}$ & $\begin{array}{r}-2,7 \% \\
-29,1 \% \\
6,8 \% \\
8,3 \% \\
11,6 \% \\
10,4 \%\end{array}$ & $\begin{array}{c}0,1 \% \\
-0,5 \% \\
13,2 \% \\
5,5 \% \\
19,3 \% \\
26,5 \%\end{array}$ & $\begin{array}{r}10,6 \% \\
2,0 \% \\
6,9 \% \\
-1,6 \% \\
-11,0 \% \\
0,0 \%\end{array}$ & $\begin{array}{c}10,6 \% \\
66,1 \% \\
20,1 \% \\
11,3 \% \\
0,6 \% \\
6,2 \%\end{array}$ \\
\hline Total Industria Agroalimentaria & $0,4 \%$ & $5,7 \%$ & $16,0 \%$ & $-3,1 \%$ & $9,9 \%$ \\
\hline Total Industria & $5,3 \%$ & $7,9 \%$ & $10,0 \%$ & $6,3 \%$ & $8,0 \%$ \\
\hline
\end{tabular}

Fuente: Eustat - Cuentas Industriales CAV. 


\section{Tasa de crecimiento real}

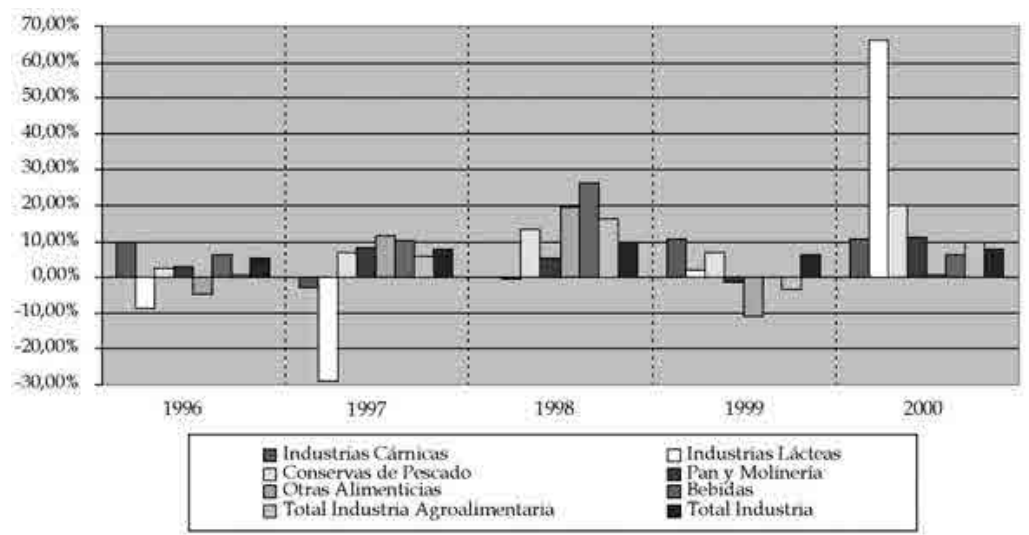

La mayor aportación a la Industria Agroalimentaria la realizan las empresas dedicadas a «Otras Alimenticias» (fabricación de aceites y grasas vegetales y animales, jugos y conservas vegetales, azúcar, pastas...) y «Bebidas» con un $30 \%$ cada uno, aunque es esta última la que ha aumentado su peso relativo desde 1995 con un crecimiento acumulado en valores reales del $58 \%$, superior a la media del Sector Industrial. Así mismo, destacamos el crecimiento acumulado real del $60 \%$ en el periodo 1995-2000 del Subsector "Conservas de Pescado» hasta situar su peso relativo en el 8,4\%. No obstante, el crecimiento acumulado del Sector Industrias Agroalimentarias ha sido del $31 \%$, inferior al $44 \%$ del total industrias, provocando una recesión de su importancia en el total pasando del 6,2 \% en 1995 al 5,7\% en el 2000.

\section{Analicemos brevemente la productividad expresada como VAB por persona:}

\begin{tabular}{|l|r|r|r|r|}
\hline \multicolumn{1}{|c|}{ Variación anual } & 1995 & 1998 & 2000 & $1995-2000$ \\
\hline Industrias Cárnicas & $23,5 \%$ & $24,4 \%$ & $24,1 \%$ & $2,6 \%$ \\
Industrias Lácteas & $60,5 \%$ & $42,2 \%$ & $61,3 \%$ & $1,3 \%$ \\
Conservas de Pescado & $25,4 \%$ & $24 \%$ & $27,4 \%$ & $7,8 \%$ \\
Pan y Molinería & $24,4 \%$ & $27,5 \%$ & $26,3 \%$ & $7,8 \%$ \\
Otras Alimenticias & $99,1 \%$ & $129,6 \%$ & $115,4 \%$ & $16,5 \%$ \\
Bebidas & $59,4 \%$ & $89,6 \%$ & $84,9 \%$ & $42,8 \%$ \\
\hline Total Industria Agroalimentaria & $46,1 \%$ & $54,4 \%$ & $51,3 \%$ & $11,3 \%$ \\
\hline Total Industria & $37,6 \%$ & $42,8 \%$ & $43,8 \%$ & $16,5 \%$ \\
\hline
\end{tabular}


La productividad de la Industria Agroalimentaria es superior a la media del Total Industria, aún cuando su crecimiento en términos reales es el periodo $1995-2000$ ha sido inferior $(11,3 \%$ respecto al $16,5 \%$ de toda la industria), correspondiendo el mayor crecimiento en productividad a los dos subsectores más dinámicos en crecimiento económico como son: "Otros Alimenticios» y «Bebidas».

\subsection{Estructura Territorial y Evolución del Sistema Agroalimentario}

Finalmente analizaremos el peso y evolución del Sistema Agroalimentario en cada Territorio Histórico.

Sector Primario

Distribución sectorial del VAB p/m. Precios Corrientes

\begin{tabular}{|c|c|c|c|c|c|c|c|c|c|c|c|c|}
\hline & \multicolumn{3}{|c|}{ CAV } & \multicolumn{3}{|c|}{ Araba } & \multicolumn{3}{|c|}{ Bizkaia } & \multicolumn{3}{|c|}{ Gipuzkoa } \\
\hline & 1995 & 2001 & $\begin{array}{c}\% \\
95-01\end{array}$ & 1995 & 2001 & $\begin{array}{c}\% \\
95-01\end{array}$ & 1995 & 2001 & $\begin{array}{c}\% \\
95-01\end{array}$ & 1995 & 2001 & $\begin{array}{c}\% \\
95-01\end{array}$ \\
\hline Agropesquero & 1,57 & 1,02 & $-1,8$ & 2,19 & 1,28 & $-8,9$ & 1,32 & 0,92 & 4,6 & 1,66 & 1,02 & 5,2 \\
\hline Industria & 36,07 & 36,04 & 51,8 & 41,89 & 45,67 & 64,4 & 31,98 & 29,99 & 40,4 & 39,56 & 41,12 & 59,5 \\
\hline Construcción & 7,33 & 7,48 & 54,9 & 6,24 & 6,87 & 71,5 & 8,36 & 8,87 & 58,8 & 6,26 & 5,67 & 38,9 \\
\hline Servicios & 55,03 & 55,46 & 53,1 & 49,68 & 46,18 & 49,1 & 58,34 & 60,22 & 54,5 & 52,52 & 52,19 & 52,6 \\
\hline$V A B p / m$ & 100 & 100 & 51,9 & 100 & 100 & 55,6 & 100 & 100 & 49,7 & 100 & 100 & 53,5 \\
\hline \multicolumn{4}{|c|}{$\begin{array}{l}\text { Participación de cada Territorio } \\
\text { Histórico en el Sector Primario }\end{array}$} & $22 \%$ & $21 \%$ & - & $43 \%$ & $46 \%$ & - & $35 \%$ & \multicolumn{2}{|l|}{$33 \%$} \\
\hline
\end{tabular}

Fuentes: Eustat - Cuentas Económicas.

El Territorio Histórico con menor participación relativa del Sector Primario es Bizkaia con el 0,92\% de la economía vizcaína, no obstante, representa el $46 \%$ del total Sector Agropesquero en la CAV. Por el contrario Araba, donde el Sector Agrario representa el 1,28\% de su economía, el mayor de los tres territorios, es el único que ha visto reducir en términos reales su aportación al VAB en el $9 \%$ en el periodo 1995-2001 y representa el $21 \%$ del total del VAB del sector en la CAV. 
Sector Industria Agroalimentaria

Distribución sectorial del VAB a Salida Fábrica. Precios Corrientes

\begin{tabular}{|c|c|c|c|c|c|c|c|c|c|c|c|c|}
\hline & \multicolumn{3}{|c|}{ CAV } & \multicolumn{3}{|c|}{ Araba } & \multicolumn{3}{|c|}{ Bizkaia } & \multicolumn{3}{|c|}{ Gipuzkoa } \\
\hline & 1995 & 2000 & $95-00$ & 1995 & 2000 & $95-00$ & 1995 & 2000 & $95-00$ & 1995 & 2000 & $95-00$ \\
\hline Industrias Cárnicas & $5,4 \%$ & $5,3 \%$ & $31,1 \%$ & $5,4 \%$ & $5,3 \%$ & $8,6 \%$ & $6,6 \%$ & $8,9 \%$ & $54,7 \%$ & $4,3 \%$ & $3,9 \%$ & $19,6 \%$ \\
\hline Industrias Lácteas & $10,3 \%$ & $8,5 \%$ & $9,1 \%$ & $17,5 \%$ & $8,5 \%$ & $25,5 \%$ & $8,6 \%$ & $3,7 \%$ & $-50,7 \%$ & $6,7 \%$ & $7,4 \%$ & $45,1 \%$ \\
\hline Conservas de Pescado & $6,9 \%$ & $8,4 \%$ & $59,5 \%$ & $0,3 \%$ & $8,4 \%$ & $189,1 \%$ & $11,2 \%$ & $15,4 \%$ & $58,4 \%$ & $7,9 \%$ & $9,6 \%$ & $57,1 \%$ \\
\hline Pan y Molinería & $17,7 \%$ & $17,4 \%$ & $29,1 \%$ & $10,0 \%$ & $17,4 \%$ & $11,6 \%$ & $27,9 \%$ & $28,1 \%$ & $15,7 \%$ & $14,4 \%$ & $17,7 \%$ & $59,9 \%$ \\
\hline Otras Alimenticias & $34,6 \%$ & $29,9 \%$ & $13,5 \%$ & $5,7 \%$ & $29,9 \%$ & $28,0 \%$ & $30,8 \%$ & $26,0 \%$ & $-3,0 \%$ & $58,1 \%$ & $53,6 \%$ & $20,0 \%$ \\
\hline Bebidas & $25,1 \%$ & $30,3 \%$ & $58,2 \%$ & $61,1 \%$ & $30,3 \%$ & $72,3 \%$ & $14,8 \%$ & $17,9 \%$ & $38,6 \%$ & $8,7 \%$ & $7,8 \%$ & $16,8 \%$ \\
\hline Total I. Alimenticia & $100 \%$ & $100 \%$ & $31,2 \%$ & $100 \%$ & $100 \%$ & $52,5 \%$ & $100 \%$ & $100 \%$ & $15,0 \%$ & $100 \%$ & $100 \%$ & $30,1 \%$ \\
\hline Total I. Aliment. s sindustria & $5,2 \%$ & $4,7 \%$ & & $8,5 \%$ & $8,3 \%$ & & $3,4 \%$ & $2,9 \%$ & & $6,2 \%$ & $5,5 \%$ & \\
\hline \multicolumn{4}{|c|}{$\begin{array}{l}\text { Participación de cada Territorio Histórico } \\
\text { en el Sector Industria Agroalimentaría }\end{array}$} & $27,6 \%$ & $31,8 \%$ & & $33,7 \%$ & $29,4 \%$ & & $38,7 \%$ & $38,7 \%$ & \\
\hline
\end{tabular}

Fuentes: Eustat - Cuentas Corrientes CAV.

El Sector de Industrias Agroalimentarias representa en Araba el $8,3 \%$ del total Industrial, importancia superior al resto de territorios con un crecimiento en el periodo 1995-2000 superior a Bizkaia y Gipuzkoa hasta representar el $32 \%$ del total de la Industria Agroalimentaria en la CAV, que se reparte casi a tercios en cada territorio siendo los subsectores más importantes en cada uno los siguientes: Araba el subsector "Bebidas» (30\%), Bizkaia el subsector «Pan y Molinería» $(28 \%)$ y en Gipuzkoa el subsector «Otras Alimenticias» (54\%).

\subsection{Situación del Asociacionismo Agrario}

A continuación, y la Caja como entidad financiera englosada dentro de la Economía Social, recogemos los principales datos que permiten definir una radiografía del estado actual de las Empresas Asociativas Agrarias (EAAs) cuya actividad es la comercialización y/o transformación de los productos agrícolas y ganaderos obtenidos en las explotaciones asociadas. Se consideran, por tanto, los datos de empresas que operan bajo la forma jurídica de cooperativas agrarias (la mayoría) y otras formas jurídicas similares como las Sociedades Agrarias de Explotación. 


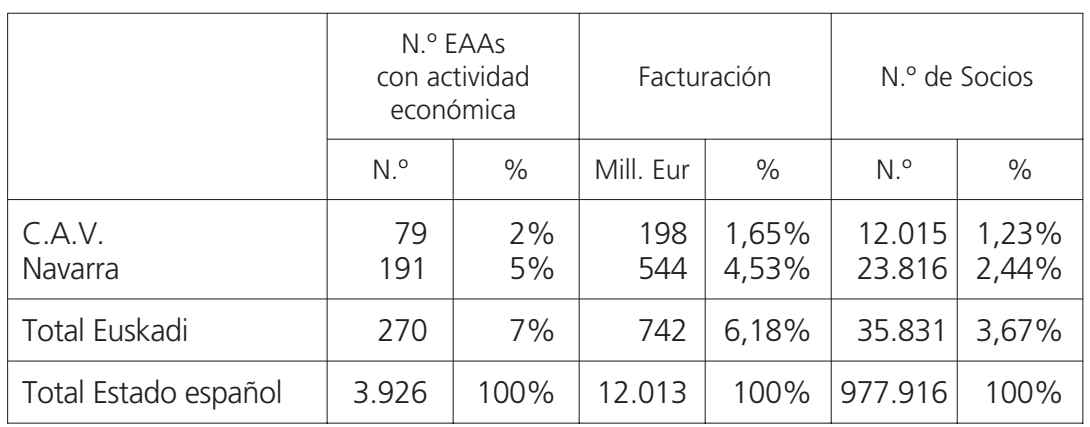

Fuente: Federación de Cooperativas Agrarias. Informe Socioeconómico del Asociacionismo Agrario Español en 2001.

Aunque a nivel general de Euskadi la presencia de la EAAs es acorde a la importancia económica respecto el total del Estado español, la C.A.V. representa sin embargo una limitada aportación, de acuerdo con el relativo poco peso específico del sector en nuestra economía.

\subsection{Situación del Sistema Agroalimentario en Ipar Kutxa - Caja Rural Vasca}

Peso en \% que representa el Sistema Agroalimentario respecto del total de Clientes y Volumen de la Caja.

\begin{tabular}{|l|c|c|c|c|c|}
\hline \multirow{2}{*}{} & \multicolumn{2}{|c|}{$\begin{array}{c}\text { Saldos } \\
\text { Acreedores }\end{array}$} & \multicolumn{2}{c|}{$\begin{array}{c}\text { Saldos Deudores } \\
\text { (Préstamos...) }\end{array}$} & $\begin{array}{c}\text { Total } \\
\text { Negocio }\end{array}$ \\
\cline { 2 - 6 } & N. ${ }^{\circ}$ Cuentas & Saldo & N. ${ }^{\circ}$ Cuentas & Saldo & Saldo \\
\hline Personas Físicas (SAA) & $8,48 \%$ & $\begin{array}{r}12,07 \% \\
7,88 \%\end{array}$ & $\begin{array}{r}9,53 \% \\
6,27 \%\end{array}$ & $\begin{array}{r}6,27 \% \\
7,69 \%\end{array}$ & $\begin{array}{r}9,44 \% \\
\text { Empresas (SAA) }\end{array}$ \\
\hline Total S.A.A. & $8,43 \%$ & $11,74 \%$ & $9,27 \%$ & $6,55 \%$ & $9,20 \%$ \\
\hline
\end{tabular}

En conjunto el Sistema Agroalimentario viene a representar en la Caja en torno al $10 \%$ del negocio, con menor importancia de las empresas, el $8 \%$, quienes mantienen un equilibrio entre sus posiciones deudoras y acreedoras, mientras que las personas físicas, fieles a su menor nivel de endeudamiento, tradicional en nuestro sistema agra- 
rio, representan el $12 \%$ de las posiciones acreedoras en la Caja y sólo el $6 \%$ de las posiciones deudoras, debiendo añadir que además el sector agroganadero se caracteriza por un bajo índice de morosidad, siendo uno de los sectores económicos que mejor responde a sus compromisos financieros.

\section{FINANCIACIÓN DE LA EMPRESA AGRARIA}

\section{A. Estructura patrimonial}

\section{A.0. Introducción}

El análisis de la financiación de la «empresa agraria» entendida como el Sector de Industrias Agroalimentarias, comenzará a partir del siguiente cuadro donde se expresan las principales masas patrimoniales y su correcto equilibrio, aplicable a cualquier tipo de empresa sin distinción sectorial.

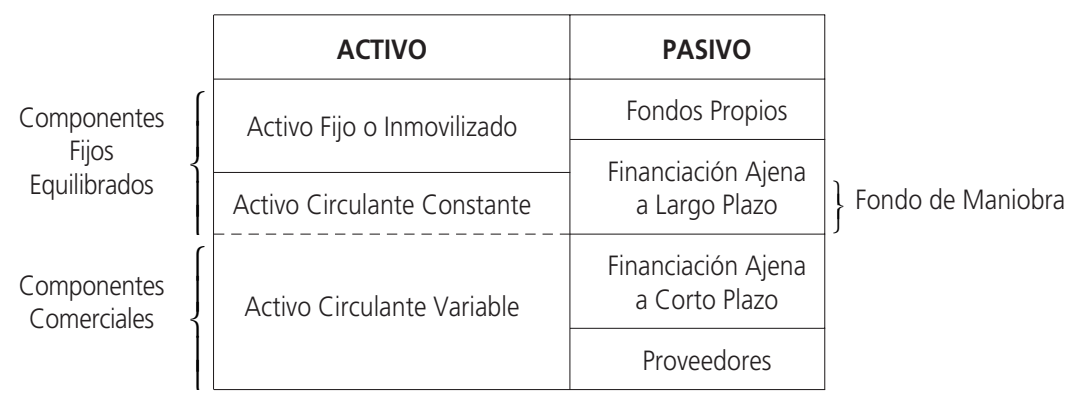

\section{A.1. Equilibrio entre Financiaciones a Corto - Largo Plazo}

Conceptos previos

—Financiación a Corto Plazo: aquella cuyo plazo de devolución es inferior o igual a 1 año.

—Financiación a Largo Plazo: aquella cuyo plazo de devolución es superior a 1 año.

La proporción fundamental depende básicamente de la correcta adecuación de la madurez del Pasivo a la del Activo, imprescindible para asegurar la solvencia futura de la empresa: 
—Necesidad de Financiación de carácter «Fijo»: hay que financiar a largo plazo los activos fijos, aquellos que representan una inversión permanente, que se recuperará a largo plazo.

— Necesidad de Financiación de carácter «Comercial»: hay que financiar a corto plazo la parte del Activo que es Circulante, aquella que tiene un periodo de maduración más corto y una liquidez mayor. Si se financian a corto plazo los activos fijos existe el riesgo de problemas de liquidez.

Periodo de maduración es el tiempo que transcurre entre el pago de la compra de las materias primas a los proveedores y el cobro de la venta de los productos a los clientes, y refleja, por tanto, de la actividad operativa habitual de la empresa.

Representación gráfica

\section{PERIODO DE MADURACIÓN}

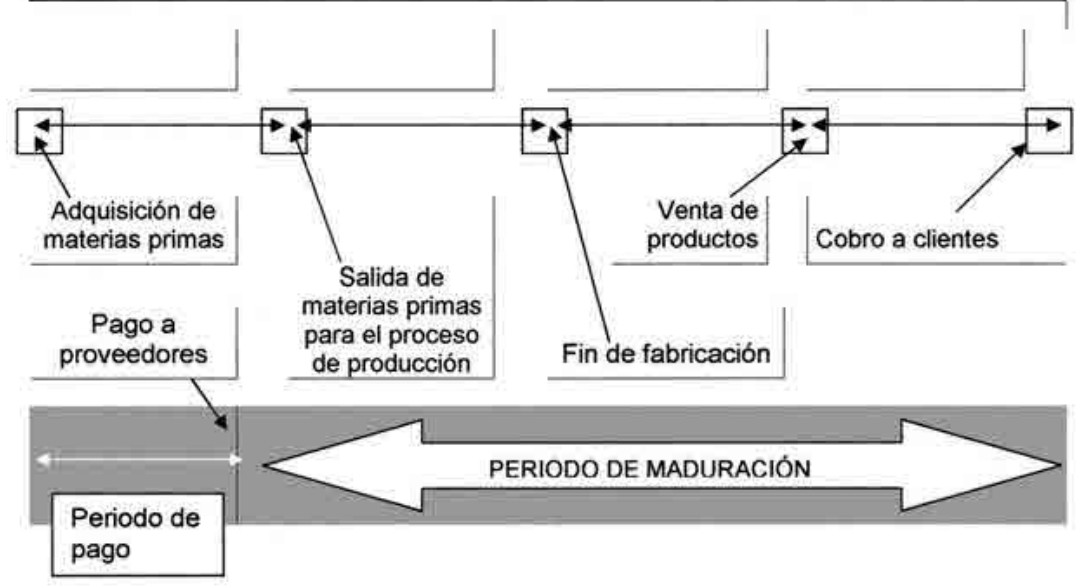

Un periodo de maduración corto supone un ritmo rápido de funcionamiento, produciéndose varias veces el ciclo de actividad durante el año (rotación). Un periodo de maduración largo supone una rotación baja, implicando una mayor necesidad de financiación, con costes más elevados y viceversa, aunque una rotación alta puede incorporar problemas de funcionamiento como escasez de productos, costes en producción... requiriendo por tanto un dimensionamiento adecuado. 
— Necesidad de Financiación de carácter «Comercial» «Constante» o «Permanente»: se corresponde con la parte del Activo Circulante que está permanentemente invertido de forma constante en cada ejercicio y que no depende de los altibajos de la cifra de negocio, luego son desfases de carácter estructural en los plazos de pago a proveedores, fabricación y cobro a clientes. Esta parte del Activo debe financiarse con Recursos a Largo Plazo y se denomina "Fondo de Maniobra», y se corresponde, por tanto, con la cuantía de los Recursos Permanentes (Fondos Propios + Financiación Ajena a Largo Plazo) que supera a las inversiones a largo (Activo Fijo). Toda empresa debe tener un Fondo de Maniobra Positivo excepto aquella cuyos Proveedores excedan del Activo Circulante como las «grandes superficies»...

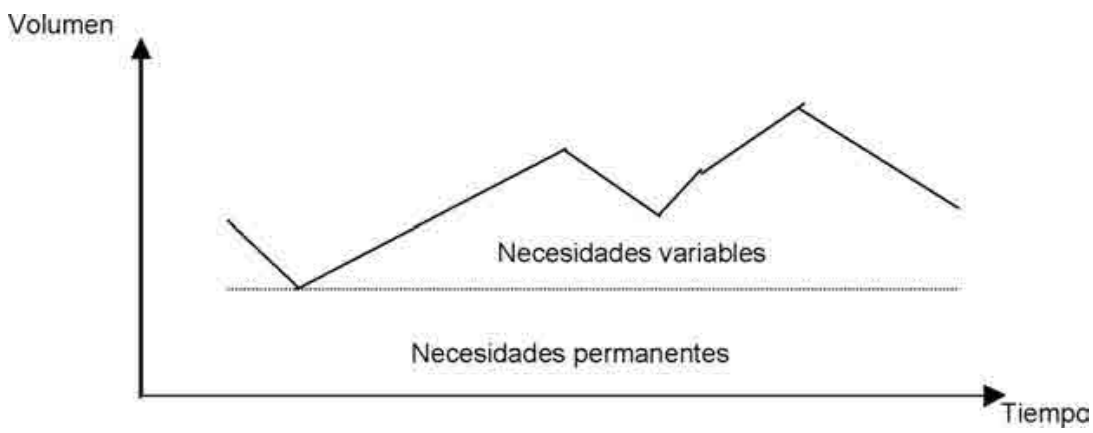

\section{A.2. Equilibrio en las Fuentes de Financiación: Fondos Propios - Financiación Ajena}

El objetivo básico de la empresa es el de conservación del «valor» de la empresa para sus socios-accionistas y si es posible, aumentar dicho valor con el tiempo, entendiendo como «valor» la percepción de un resultado líquido (en forma de dividendo repartido o de asignación a reservas) que sobre el valor del capital invertido por el socio-accionista le suponga una rentabilidad similar o superior al de otras inversiones de parecido riesgo asumido, ya que de otra forma el valor de la empresa se reduce automáticamente ya que nadie estará dispuesto a pagar por dicha empresa su valor inicial. 
La gestión financiera a largo plazo del «valor de la empresa» incide en dos aspectos:

- Reducir los recursos invertidos eliminando las inversiones con rentabilidad inferior a la deseada.

- Gestionar los capitales propios-ajenos utilizados para financiar el negocio.

El equilibrio de Recursos Propios / Ajenos debe responder de forma adecuada al binomio Riesgo - Rentabilidad.

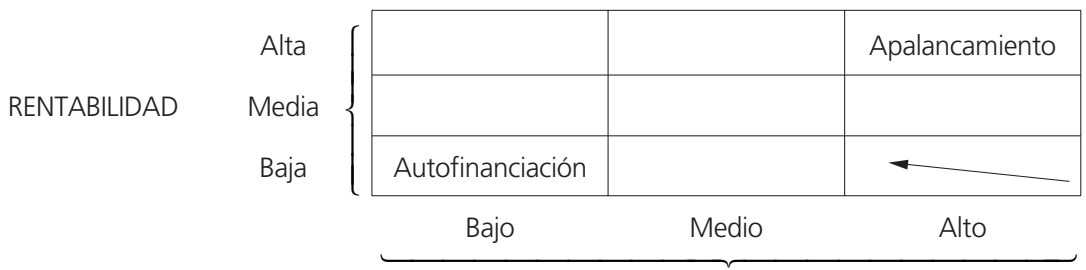

RIESGO

- Cuantos más recursos propios existe un menor riesgo, pero a costa de una menor rentabilidad. Es ejemplo de una empresa conservadora que al tener limitada su capacidad de crecimiento a su capacidad de generación o aportación de recursos propios, pierde oportunidades en épocas de bonanza pero sobrevive en épocas de dificultades.

- Cuantos más recursos ajenos existe un mayor riesgo (de interés, o no poder atender los pagos...), pero con una mayor rentabilidad. Un activo financiado íntegramente con Recursos Propios por 1.000 y que obtiene un beneficio antes de impuestos de 148 y después de importe de 100, obtiene una rentabilidad del $10 \%$ (10/1000), pero si la mitad (500) se financia con un préstamo a largo plazo al $12 \%$, el beneficio bruto y neto serían de 88 y de 59,4 respectivamente, con una rentabilidad del 11,88 \% $(59,4 / 500)$.

La opción óptima estará en una solución intermedia que tienda a reducir el riesgo y aumentar la rentabilidad y el equilibrio entre autofinanciación y apalancamiento exigirá reducir ambas posiciones extremas (menos del $75 \%$ de los recursos) y dependerá de varias circunstancias como la filosofía más o menos conservadora de la propiedad y dirección de la empresa y las estimaciones sobre los tipos de interés. 
Para controlar esta estrategia es conveniente utilizar los ratios de:

1. «Rendimiento bruto/neto de los Activos» (expresa la importancia del beneficio respecto al valor del capital invertido en el negocio y depende del «Margen sobre Venta» y de la «Rotación de Activos»), y

2. «Rentabilidad de los Recursos Propios» (expresa la importancia del beneficio respecto al valor de los recursos invertidos en la empresa por el socio-accionista y depende del «Rendimiento de los Activos» y del «Apalancamiento»).

\section{A.3. Comparativa Estructura Industrias Agroalimentarias}

\begin{tabular}{|c|c|c|c|c|c|c|c|c|c|c|c|c|c|c|c|c|c|c|c|c|c|}
\hline & \multicolumn{2}{|c|}{1991} & \multicolumn{2}{|c|}{1992} & \multicolumn{2}{|c|}{1993} & \multicolumn{2}{|c|}{1994} & \multicolumn{2}{|c|}{1995} & \multicolumn{2}{|c|}{1996} & \multicolumn{2}{|c|}{1997} & \multicolumn{2}{|c|}{1998} & \multicolumn{2}{|c|}{1999} & \multicolumn{2}{|c|}{2000} \\
\hline & & $\mathbb{M}$ & IABT & IM & IABT & $\mathbb{M}$ & $\mid$ IABT & $\mathbb{I M}$ & |ABT & $\mathbb{M}$ & |ABT & $\mathbb{M}$ & IABT & IM & IABT & $\mathbb{I M}$ & | IABT & $\mathbb{M}$ & AABT & $\mathbb{M}$ & IABT \\
\hline $\begin{array}{l}\text { Rentabilidad Ordinaria del Activo Neto* } \\
\text { Intereses por Recursos Ajenos con Coste } \\
\text { Rentabilidad Ordinaria de Recursos Propios** } \\
\text { Apalancamiento (R1-R2) } \\
\text { Ratio Endeudamiento*** }\end{array}$ & $\begin{array}{l}\text { R1 } \\
\text { R2 } \\
\text { R3 } \\
\text { R4 } \\
\text { R5 }\end{array}$ & $\begin{array}{c}6,7 \\
13 \\
3,8 \\
-6,4\end{array}$ & $\begin{array}{r}12,3 \\
13,9 \\
11,8 \\
-1,6\end{array}$ & $\begin{array}{c}4 \\
12,6 \\
-0,4 \\
-8,6\end{array}$ & \begin{tabular}{|c}
9,5 \\
13 \\
8,3 \\
$-3,5$
\end{tabular} & $\begin{array}{r}2,4 \\
12,2 \\
-3,4 \\
-9,8\end{array}$ & \begin{tabular}{|c|}
7,7 \\
13,6 \\
5,6 \\
-6
\end{tabular} & $\begin{array}{r}7,3 \\
9,5 \\
6,1 \\
-2,2\end{array}$ & $\begin{array}{r}9,3 \\
10,4 \\
8,9 \\
-1,1\end{array}$ & $\begin{array}{r}10,5 \\
9,5 \\
10,9 \\
0,9\end{array}$ & $\begin{array}{c}9,9 \\
10 \\
9,9 \\
-0,1\end{array}$ & $\begin{array}{r}9,2 \\
8,3 \\
9,5 \\
0,9 \\
36,6\end{array}$ & $\begin{array}{c}9,6 \\
9,6 \\
9,6 \\
0 \\
30,1\end{array}$ & $\begin{array}{r}10,4 \\
7,1 \\
11,7 \\
3,3 \\
33,3\end{array}$ & $\begin{array}{c}10,1 \\
7,5 \\
11 \\
2,6 \\
31,7\end{array}$ & $\begin{array}{r}11,3 \\
5,9 \\
13,4 \\
5,4 \\
32,7\end{array}$ & $\begin{array}{r}11,4 \\
5,9 \\
13,1 \\
5,5 \\
28,3\end{array}$ & $\begin{array}{r}10,9 \\
4,5 \\
13,3 \\
6,4 \\
32,5\end{array}$ & $\begin{array}{r}10,5 \\
4,1 \\
12,6 \\
6,4 \\
32,2\end{array}$ & $\begin{array}{c}11,3 \\
5,4 \\
13,8 \\
6 \\
36,3\end{array}$ & $\begin{array}{r}8,8 \\
4,9 \\
10,4 \\
3,9 \\
39,5\end{array}$ \\
\hline
\end{tabular}

* (Resul. ordinario neto + Int. por financiación/Activo Neto = Pasivo Remunerado)

(donde: Activo Neto = Activo Inmovilizado + Circulante Neto (-Financ.C.P.sin coste) - Provisiones)

(donde: Pasivo Remunerado = Financ. Permanente (RRPP + Rec. Ajenos a L.P. $)+$ Financ. a C.P. con coste)

Verdadera rentabilidad de las empresas, independientemente de cómo se financien, y mide la adecuación con que las empresas utilizan sus recursos e inversiones.

** Si R1 es > a R2 entonces R3 es superior a R1 y al revés.

*** Recursos Aienos con coste/Pasivo Remunerado.

NoтA: IM: Industria Manufacturera y IABT: Industria de la Alimentación, Bebidas y Tabaco

Fuente: Banco de España Central de Balances. Resultados anuales de las empresas no financieras.

Si analizamos inicialmente la rentabilidad de las empresas, independientemente de cómo se financien para medir la adecuación con que las empresas utilizan sus recursos e inversiones, a través de la «Rentabilidad Ordinaria del Activo Neto» observamos que hasta 1995 la Industria Agroalimentaria era más eficiente que la Industria Manufacturera en general, situación que se equilibra hasta el ejercicio 2000 en el que se da la vuelta, no obstante se ve una menor volatilidad en los resultados de la Industria Agroalimentaria con una rentabilidad más homogénea.

Hasta el año 1995 en que las empresas obtenían un apalancamiento negativo por una rentabilidad de sus activos, inferior al coste de sus Recursos Ajenos, éstas entrarán en pérdidas salvo que reduzcan su endeudamiento y actividad o aumenten el capital, y en este 
caso la Rentabilidad Ordinaria de los Recursos Propios será inferior a la Rentabilidad del Activo Neto, y el análisis entre las diferentes industrias de la Rentabilidad de los Recursos Propios es similar al del Activo Neto.

Finalmente respecto al ratio de endeudamiento, no hay mucha diferencia entre las diferentes industrias salvo un mayor repunte del endeudamiento en las industrias Agroalimentarias en el año 2000.

\section{B. Fórmulas de financiación}

\section{B.1. Fondos Propios}

Las formas de obtener recursos propios son básicamente dos: aportación al capital y la Autofinanciación.

\section{B.1.1. Participación Directa}

La Caja ostenta actualmente participaciones, de carácter no financiero en el Capital Social de tres empresas del Sector Agroalimentario.

\begin{tabular}{|l|l|l|}
\hline \multicolumn{1}{|c|}{ Sector } & Denominación social & Forma jurídica \\
\hline Lácteo & IPARLAT & S. Anónima \\
Alimentos para animales & Piensos del Norte & S. Anónima \\
Patatas & UDAPA & S. Cooperativa \\
\hline
\end{tabular}

La participación de nuestra entidad en estas empresas hay que entenderla como decisiones de apoyo en un momento histórico puntual cuando por una u otras circunstancias estas empresas atravesaron momentos de necesidad financiera o incluso de tener un socio de referencia con suficiente capacidad financiera para apoyar dichas iniciativas. La preocupación fundamental de la Caja al apoyar esta decisión era la enorme repercusión que la viabilidad de este proyecto tenía en las explotaciones individuales de los agricultores y ganaderos de nuestra zona de implantación. Y nuestra permanencia en dichas sociedades también debe entenderse en el mismo sentido.

De lo anterior se entiende nuestro posicionamiento «reticente» respecto a las participaciones industriales de carácter no financiero de 
la Caja y más genéricamente del papel que deben jugar las entidades financieras en las relaciones accionariales banca-empresa.

Aún cuando estamos inmersos en un modelo «continental» de sistema financiero, que a diferencia del modelo «anglosajón» y tanto por motivos históricos como por diferentes grados de desarrollo de los mercados de valores, existe una vinculación muy fuerte con las empresas no financieras, entendemos que sus aspectos negativos y debilidades superan a las ventajas, desde el punto de vista de participación de la Caja.

Creemos que la implicación del sector financiero en las empresas no financieras, además de posibilitar una mayor resistencia a reestructuraciones ante escenarios económicos adversos que perpetúan la agonía de sectores ineficaces y limitando una auténtica competencia, ante crisis de carácter estructural esta vinculación supone una barrera real de salida de la entidad financiera, pudiendo incluso aumentar la vinculación y consiguiente riesgo de pérdida de confianza del público ante el posible efecto contagio de la crisis.

Actualmente pueden surgir de las relaciones banca-empresa, posibles conflictos de intereses derivados de la doble fidelidad a la que se deben sus gestores y/o posibles consejeros comunes ante decisiones, por ejemplo, del aumento excesivo o no del endeudamiento, con los mayores beneficios para la entidad financiera, o incluso en las decisiones industriales por diferentes enfoques de riesgo.

Finalmente el negocio inducido por el posible negocio financiero derivado de las participaciones banca-empresa, pueden contribuir a largo plazo a una excesiva concentración de riesgos, aún cuando a corto plazo puede ser rentable.

En conclusión y basado tanto en nuestra reducida vocación inversora, como en nuestra historia y realidad actual a este respecto, vemos con reticencia una participación accionarial de carácter no financiero en empresas industriales optando por centrarnos en nuestra actividad financiera tradicional, aunque sin abandonar las responsabilidades que asumimos con las participaciones actuales.

\section{B.1.2. Participación Indirecta, a través de las Sociedades de Capital Riesgo}

Las sociedades de capital riesgo invierten recursos en empresa con el objetivo de obtener una rentabilidad de la inversión vinculada al futuro de la empresa con las siguientes características: 
- El fin que persigue no es una toma de posición de control de la empresa sino participar minoritariamente en los recursos propios de ésta.

- La participación no tiene vocación de permanencia, sino que, una vez madurado el proyecto, se recupera el capital con la correspondiente plusvalía.

—Finalmente los destinatarios de la participación suelen ser empresas que no cotizan en Bolsa y que necesitan financiar su crecimiento.

Este tipo especial de inversión y con elevado riesgo, al tratarse de proyectos o lanzamiento de empresas innovadoras, requiere de un intermediario financiero especializado, normalmente de iniciativa pública y que además ofrece servicios como el asesoramiento, control del proyecto de inversión, orientación y cobertura técnica...

La Caja participa en el capital de SEED CAPITAL DE BIZKAIA, Sociedad Gestora de Entidades de Capital Riesgo, S.A. Sociedad Pública de la Diputación Foral de Bizkaia destinada a la administración del Fondo denominado SEED CAPITAL DE BIZKAIA, Fondo de Capital Riesgo cuyo objeto es la promoción y desarrollo de empresas mediante la participación temporal en su capital, o mediante créditos participativos (www.seedcapitalbizkaia.net).

La misión de SEED CAPITAL es la «promoción y desarrollo de empresas de nueva creación o existentes, que pretendan el desarrollo de proyectos innovadores, nuevos productos, mercados o procesos productivos, mejoras en la gestión, estabilidad o continuidad, proyección de futuro, creación de empleo estable y generación de riqueza».

De la veintena de proyectos en los que participa, hay uno cuyo actividad está relacionada con el Sector Agroalimentario MedPlant Genetics, S.L. y cuya actividad se dedica al "Desarrollo y Comercialización de soluciones de Biotecnología en el diagnóstico y tratamiento de problemáticos de salud humana, medioambiental y de bioseguridad alimentaria».

Como observamos el Capital Riesgo es un instrumento adicional para las empresas relacionadas con el Sector Agroalimentario aunque limitado por el carácter que se requiere de los proyectos.

Condición de los Préstamos Participativos (préstamos en los que el tipo de interés se determina en función de los resultados de la em- 
presa y su exigibilidad puede subordinarse a los demás acreedores comunes):

Tipo de Interés: $\quad$ Fijo: Euribor a 3 meses + 0,25.

Variable: en función del resultado del ejercicio.

El coste conjunto máximo: Euribor a 3 meses + 5 .

Plazo Amortización: 7 años con 2 años de carencia.

Comisión Apertura: 0,5\%.

\section{B.1.3. AutofinANCIACión}

Supone la reinversión de los recursos generados, a través de la Retención de Beneficios, que pueden tomar la forma de reservas, fondos de amortización y provisiones.

La política de dividendos (en Sociedades Anónimas...) o retornos cooperativos (en Sociedades Cooperativas) forman parte de las decisiones estratégicas de la empresa y que se debe conjugar con la existencia o no de beneficio distribuible definido como la parte de la renta generada por la empresa y que una vez remunerados todos los factores externos, corresponde a los socios / accionistas.

Los aspectos que se deben tener en cuenta a la hora de determinar la política de dividendos / retornos son:

-El beneficio contable está sobrevalorado ya que el gasto de amortización se fundamenta en valores históricos.

-El beneficio distribuible se determina en función del criterio de devengo y los dividendos / retornos suponen una salida de tesorería.

-El socio / accionista adverso al riesgo (volatilidad de rentas de capital) y/o preocupado por la liquidez deseará una estabilidad en el pago de dividendos / retornos.

Las empresas más restrictivas en el pago de dividendos (según un estudio del Banco de España) son:

—Las del Sector Público y las que pertenecen a particulares en al menos un $33 \%$ del capital.

- Las de menor dimensión y que no cotizan en bolsa.

— Las que tienen más restringido su acceso a fuentes de financiación ajena. 
En las cooperativas agrarias hay una tendencia a recurrir al sistema de retornos de cooperativas por parte de los socios, surgiendo tensiones ante la necesaria política de fortalecimiento de los recursos de la empresa que deben salvaguardar los gestores y órganos de administración.

\section{B.1.4. Recursos Propios mediante acceso al Mercado Bursátil}

Es un sistema de financiación especialmente indicado para la gran empresa, pero también se pueden acoger las PYMES con vocación de crecimiento a través del "Segundo Mercado» donde los requisitos de entrada son menos rigurosos. Decisión estratégica con difícil «vuelta atrás», convirtiéndose la bolsa en indicador de la gestión, rentabilidad y perspectivas de crecimiento de la empresa.

La cotización en Bolsa para las PYMES tienen algunas ventajas:

-Facilita soluciones financieras (captar nuevos capitales, equilibrar la estructura financiera RRPP / RRAA...).

- Resuelve problemas patrimoniales de los socios (proporciona liquidez al accionista, salida de socios minoritarios, resuelve temas sucesorios...).

— Razones de Notoriedad (admisión y cotización en bolsa).

A pesar de lo cual no se ha producido un desarrollo de estos mercados con escasa liquidez de sus títulos por el riesgo de la pérdida de control por sus socios y la reticencia tradicional a facilitar información a terceros.

\section{B.2. Financiación Pública - Subvenciones}

\section{B.2.0. INTRODUCCIÓN}

El Sector Agroalimentario, en su conjunto, está muy ligado tanto a las ayudas directas ligadas a la producción como a las ayudas para el «Desarrollo Rural».

En este apartado incluiremos todo tipo de «Ayudas», entendidas no sólo las subvenciones directas, sino cualquier otra intervención, de carácter indirecto, que bajo formas diversas aligeran las cargas que normalmente gravan el presupuesto de una empresa, intervenciones de asistencia de carácter no financiero (conjunto de entidades de iniciativa pública y/o privada que complementan las actuaciones institu- 
cionales públicas con objeto de potenciar y desarrollar todas las actividades relacionadas con el Sector Agroalimentario).

El conjunto de ayudas y subvenciones al Sector Agroalimentario, a mi juicio, y en general se deben entender no como una mera intervención pública que distorsiona la competencia, sino como la contraprestación del conjunto de la ciudadanía, a través de las instituciones públicas, por todas aquellas funciones que desarrolla el Sector Primario y su industria y que no tienen valoración económica en las transacciones mercantiles, en el sentido de que la sociedad solicita de su espacio rural sea multifuncional:

-Que proporcione alimentos de calidad que preserven la salud pública, evitando las amenazas e inseguridades.

- Que proteja activamente su patrimonio natural.

-Que gestione y ocupe racionalmente el territorio y proporcione servicios turísticos, de ocio... en contacto con la naturaleza.

\section{B.2.1. CRItERIOS Y AyudAs COMUnitARIAS}

Respecto a la política de subvenciones en la Unión Europea, el art. 33 del Tratado CE define los objetivos de la PAC y dispone que, en la elaboración de esta política y de sus métodos especiales de aplicación, se tengan en cuenta tres factores principales: las características particulares de la actividad agraria, resultantes de la propia estructura de la agricultura y de las desigualdades estructurales y naturales entre las regiones agrícolas; la necesidad de introducir gradualmente las adaptaciones que sean oportunas; y el hecho de que la agricultura sea un sector que está estrechamente vinculado al conjunto de la economía.

Las nuevas Directrices comunitarias con entrada en vigor el 01/01/2000, que regulan con claridad los diferentes tipos de ayudas estatales que se autorizan, tienen en cuenta las nuevas orientaciones de la política agrícola y, en especial, los objetivos de mejorar y fomentar la calidad de los productos del sector y de preservar el medio ambiente y el patrimonio tradicional.

Las nuevas Directrices parten del principio de que toda ayuda estatal al sector agrario debe ser compatible con las políticas agrícola y de desarrollo rural y con las obligaciones internacionales de la Co- 
munidad, en especial las derivadas del Acuerdo de Agricultura de la OMC. Quedan prohibidas así las ayudas estatales que puedan alterar los mecanismos de las organizaciones comunes de mercados (OCM). Debe tenerse en cuenta que, al aceptar los Reglamentos de esas organizaciones, los Estados miembros renunciaron a la posibilidad de adoptar medidas de ayuda unilaterales que interfieran en el apoyo comunitario a los precio de los productos.

Además, de acuerdo con los principios establecidos por el Tribunal de Justicia, las ayudas estatales deben hacer una contribución real al desarrollo de determinadas actividades económicas o de ciertas regiones. Las ayudas estatales que sólo se proponen mejorar la situación económica del beneficiario, sin ninguna contrapartida por su parte, no pueden considerarse en ningún caso compatibles con el Tratado CE.

Cuadros de las Ayudas Estatales

Ayudas estatales en los Estados miembros, 2000

\begin{tabular}{|l|c|c|c|c|c|c|c|c|c|c|c|c|c|c|c|c|}
\hline & EU & B & DK & D & EL & E & F & IRL & I & L & NL & A & P & FIN & S & UK \\
\hline $\begin{array}{l}\text { Total ayudas estatales } \\
\text { en millones de euros }\end{array}$ & 82,4 & 3,3 & 2,4 & 25,0 & 1,1 & 5,8 & 15,7 & 1,2 & 10,4 & 0,2 & 3,8 & 2,0 & 1,3 & 1,8 & 1,8 & 6,5 \\
\hline $\begin{array}{l}\text { Total ayudas estatales } \\
\text { en \% del PIB }\end{array}$ & 0,99 & 1,34 & 1,23 & 1,23 & 0,89 & 0,99 & 1,13 & 1,20 & 0,92 & 1,24 & 0,98 & 0,97 & 1,18 & 1,44 & 0,75 & 0,46 \\
\hline
\end{tabular}

Fuente: DG Competencia. Comisión de las Comunidades Europeas.

\section{Disparidades entre Estados miembros en cuanto al volumen de ayudas estatales en porcentaje del PIB.}

En términos relativos, las ayudas estatales ascendieron al 0,99\% del Producto Interior Bruto (PIB) de la Unión Europea en 2000. Este promedio encubre las enormes disparidades existentes entre los Estados miembros: la proporción que suponen las ayudas respecto del PIB oscila entre el $0,46 \%$ en el Reino Unido y el 1,44\% en Finlandia. El elevado porcentaje de Finlandia puede explicarse porque el volumen de las ayudas a la agricultura es relativamente alto; representa el $70 \%$ del total de las ayudas en este país. Las cifras relativas a Grecia, España, Italia, los Países Bajos, Austria y Suecia se sitúan a la altura o por debajo del promedio de la UE. 


\section{Distribución Sectorial de las ayudas estatales}

\section{La distribución sectorial de las ayudas varía considerable-}

mente de un Estado miembro a otro y a lo largo del tiempo.

En 2000, el $39 \%$ de las ayudas estatales concedidas en la Unión se destinó al sector del transporte, casi exclusivamente a la red de transporte por ferrocarril. El sector industrial recibió el $29 \%$ del total, la agricultura y la pesca el $17 \%$ significativo respecto al $1 \%$ que representa el sector en el PIB y la industria del carbón el $9 \%$.

Hay diferencias importantes entre Estados miembros en cuanto a los sectores beneficiarios de las ayudas. Alemania sólo destina a la agricultura y la pesca el $7 \%$ del total de las ayudas estatales, mientras que en Finlandia esta cifra se eleva al $73 \%$.

En el Estado español, la Agricultura representa el $24 \%$ del total de ayudas estatales, por encima del $17 \%$ de media comunitaria.

Distribución Sectorial de las Ayudas, 2000

\begin{tabular}{|c|c|c|c|c|c|c|c|}
\hline \multicolumn{7}{|c|}{$\begin{array}{c}\% \\
\text { del total }\end{array}$} & \multirow{2}{*}{$\begin{array}{c}\begin{array}{r}\text { millones } \\
\text { de euros }\end{array} \\
\text { Total }\end{array}$} \\
\hline & Industria & $\begin{array}{c}\text { Servicios } \\
\text { (turismo, serv. } \\
\text { financieros, } \\
\text { medios de } \\
\text { com. y cultura) }\end{array}$ & Transporte & $\begin{array}{l}\text { Agricultura } \\
\text { y Pesca }\end{array}$ & Carbón & Sin calificar* & \\
\hline EU & 29 & 3 & 39 & 17 & 9 & 4 & 82.373 \\
\hline B & 18 & 1 & 64 & 12 & 0 & 6 & 3.292 \\
\hline DK & 43 & 1 & 30 & 12 & 0 & 14 & 2.412 \\
\hline D & 36 & 0 & 39 & 7 & 19 & 0 & 25.044 \\
\hline EL & 37 & 1 & 48 & 14 & 0 & 0 & 1.085 \\
\hline$E$ & 21 & 1 & 23 & 24 & 19 & 13 & 5.833 \\
\hline $\mathrm{F}$ & 29 & 5 & 39 & 21 & 6 & 0 & 15.689 \\
\hline IRL & 40 & 13 & 11 & 33 & 0 & 3 & 1.196 \\
\hline I & 31 & 2 & 48 & 16 & 0 & 3 & 10.433 \\
\hline $\mathrm{L}$ & 15 & 2 & 72 & 12 & 0 & 0 & 245 \\
\hline $\mathrm{NL}$ & 19 & 1 & 53 & 28 & 0 & 0 & 3.799 \\
\hline$A$ & 20 & 1 & 33 & 44 & 0 & 1 & 1.965 \\
\hline $\mathrm{P}$ & 16 & 40 & 7 & 22 & 0 & 15 & 1.322 \\
\hline FIN & 22 & 1 & 2 & 73 & 0 & 2 & 1.833 \\
\hline$S$ & 24 & 6 & 47 & 23 & 0 & 0 & 1.769 \\
\hline UK & 19 & 2 & 39 & 16 & 3 & 20 & 6.459 \\
\hline
\end{tabular}

* Esta columna incluye las ayudas al empleo y a la formación que no pueden clasificarse dentro de un sector específico. Fuente: DG Competencia. Comisión de las Comunidades Europeas. 
Reforma de la Política de Ayudas Estatales de los Estados Miembros

\section{Los Estados miembros están reorientando las ayudas hacia objetivos horizontales.}

Por lo general, suele considerarse que las ayudas estatales a objetivos horizontales, es decir, las que no se conceden a un determinado sector o zona geográfica, se destinan a paliar deficiencias del mercado y no falsean la competencia en el mismo grado que las ayudas sectoriales y las ayudas ad hoc. Las actividades de investigación y desarroIlo, la preservación del medio ambiente, el ahorro de energía y el apoyo a las pequeñas y medianas empresas son los objetivos horizontales más importantes abordados por las ayudas estatales.

\section{B.2.2. CRIterios y Ayudas en la C.A.V.}

Veamos a continuación cuáles han sido y son en la actualidad las políticas de subvenciones en la C.A.V. con el objetivo genérico del desarrollo de la Agricultura Vasca.

Etapas de la historia reciente de la Agricultura Vasca

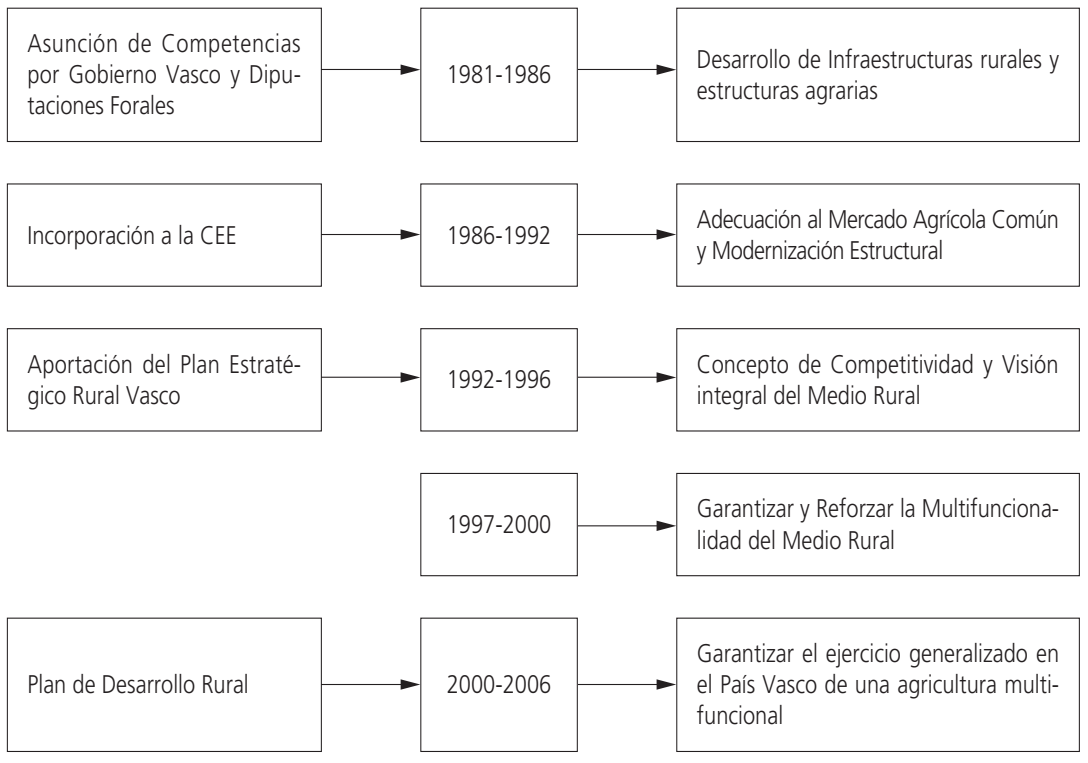


El actual Plan de Desarrollo Rural Sostenible de la C.A.V. pretende «Garantizar el ejercicio generalizado en el País Vasco de una agricultura multifuncional» con una estrategia de desarrollo rural fundamentada en la combinación de actuaciones encaminadas a incluir de forma dual en la sostenibilidad de la actividad y del entorno, continuidad del Plan Estratégico Rural Vasco 1992-96 que constituyó un cambio cualitativo fundamental y donde el concepto de multifuncionalidad adquiere sus actuales dimensiones con tres grandes funciones:

1. Función Económica: El espacio rural tiene una primera y gran función como soporte a la provisión de alimentos de calidad garantes de la salud pública, pero también es lugar para la instalación de pequeñas y medianas empresas industriales, artesanales y comerciales, así como de prestación de servicios, entre las que las relacionadas con el ocio, el turismo y el descanso adquieren especial interés.

2. Función Ecológica: El espacio rural soporta los espacios naturales y los paisajes bien conservados. En él tienen cabida numerosos biotópos y hábitats faunísticos. El espacio rural conserva la fauna y el patrimonio forestal y es el ámbito natural para actividades de ocio y descanso. Las funciones ecológicas del espacio rural tratan de preservar las bases naturales de la vida - el suelo, el agua, el aire-, y tratan también de proteger los espacios verdes, así como de preservar y conservar el paisaje construido por el hombre a lo largo de la historia.

3. Función Socio-Cultural: El espacio rural tiene también como función asegurar y aumentar su papel socio-cultural, principalmente a través del desarrollo de la vida asociativa local y del incremento de relaciones con la población urbana.

\section{Plan de Desarrollo Rural Sostenible (2000-2006)}

El actual Plan de Desarrollo Rural Sostenible (2000-2006) contiene total la financiación comunitaria correspondiente a la C.A.V. en virtud del Reglamento (CE) n. ${ }^{\circ}$ 1257/1999 de Desarrollo Rural con fondos del FEOGA (Fondo Europeo de Orientación y Garantía Agraria) por importe de 121 millones de euros, complementado por las aportaciones de las administraciones vascas por 115 millones de euros, y que tras un «diagnóstico» de la situación actual tanto inherente al sector como al contexto externo al mismo, ha establecido una jerarquización de los 
problemas e identificación coherente de las diferentes prioridades establecidas en las diferentes «medidas» a Desarrollar.

—Diagnóstico de la Situación del Sector (Análisis DAFO).

\begin{tabular}{|c|c|}
\hline Debilidades & Fortalezas \\
\hline $\begin{array}{l}\text { 1. Reducido número de em- } \\
\text { presas agroalimentarias } \\
\text { que generan valor añadi- } \\
\text { do y empleo. } \\
\text { 2. Insuficiente orientación de } \\
\text { la oferta hacia el mercado. } \\
\text { 3. Estructura minifundista de } \\
\text { las explotaciones agrarias. } \\
\text { 4. Envejecimiento de la po- } \\
\text { blación agraria. } \\
\text { 5. Insuficientes equipamien- } \\
\text { tos en infraestructuras. }\end{array}$ & $\begin{array}{l}\text { 1. Existencia de estructuras y organismos de } \\
\text { promoción: Instituto de Desarrollo Rural y } \\
\text { Asociaciones de Agricultura de Montaña. } \\
\text { 2. Población rural muy identificada con su } \\
\text { actividad y consciente de su labor en la } \\
\text { gestión del territorio y conservación de } \\
\text { valores culturales. } \\
\text { 3. Producción reconocida de diversos pro- } \\
\text { ductos acogidos a distintivos de calidad y } \\
\text { denominaciones de origen. } \\
\text { 4. Redacción en curso de un Plan Territorial } \\
\text { Sectorial agroforestal en el que se plan- } \\
\text { tean actuaciones concretas contra la se- } \\
\text { gregación parcelaria y la insuficiente di- } \\
\text { mensión de las explotaciones agrarias. } \\
\text { 5. Carácter multinacional de la gestión sos- } \\
\text { tenible de los bosques vascos. } \\
\text { 6. Existencia de una demanda estable de } \\
\text { madera de la zona. } \\
\text { 7. Existencia de una política institucional } \\
\text { tendente a minimizar las presiones sobre } \\
\text { ocupación del suelo agrario. }\end{array}$ \\
\hline Amenazas & Oportunidades \\
\hline $\begin{array}{l}\text { 1. Orientación general de la } \\
\text { sociedad a modelos de de- } \\
\text { sarrollo urbano-industrial. } \\
\text { 2. Presiones sobre el suelo } \\
\text { agrario: procesos de urba- } \\
\text { nización e infraestructuras. } \\
\text { 3. Internacionalización y libe- } \\
\text { ralización de los mercados } \\
\text { agrarios. }\end{array}$ & $\begin{array}{l}\text { 1. Aceptación de la producción agraria vasca } \\
\text { en los mercados. } \\
\text { 2. Potencialidad de crecimiento de los pro- } \\
\text { ductos agrarios. } \\
\text { 4. Creciente demanda de manera a nivel } \\
\text { mundial. } \\
\text { 5. Existencia de producciones de madera de } \\
\text { calidad para la industria del mueble. } \\
\text { 6.--Demanda social de espacios naturales } \\
\text { bien conservados y de una producción } \\
\text { sostenible. } \\
\text { 7. Atractivo turístico de las zonas rurales en } \\
\text { aumento en base a su riqueza natural y } \\
\text { paisajística. }\end{array}$ \\
\hline
\end{tabular}


- Medidas a desarrollar con identificación de las autoridades responsables.

Las prioridades del plan de desarrollo rural sostenible irán orientadas a consolidar la actividad agraria como integrante significativo del tejido socioeconómico rural; potenciando tanto la orientación de producciones con mayores garantías de salida al mercado como las prácticas más respetuosas con el entorno natural y que propicien un desarrollo de la actividad más sostenible.

En este sentido serán considerables los esfuerzos en apoyar la viabilidad de las explotaciones agrarias a través de las ayudas a la inversión que propicien estructuras productivas adecuadas a cada sector: actuando a favor del redimensionamiento en superficie y de la tendencia a la profesionalización de las explotaciones y de los activos sectoriales. Ambas líneas de orientación se complementan con la potencialidad de los activos del sector, dada la oportunidad de disponer de jóvenes agricultores con formación que esperan dar el relevo en la titularidad de las explotaciones, y que están, en mayor medida, comprometidos con aspectos agroambientales y con políticas de calidad en la producción.

Adicionalmente, se considera prioritario incentivar la mayor implicación de los activos en la cadena valor agroalimentaria de los diferentes sectores, a través de iniciativas tanto dentro como fuera de las explotaciones. Así, se apuesta por un apoyo a la participación de los productores en las fases de transformación y comercialización que irá destinado principalmente a fomentar productos de calidad. Paralelamente se considera fundamental, en este proceso de propiciar la generación de mayor valor añadido, un apoyo a iniciativas que aunque no directamente implicadas en la producción son determinantes para el desarrollo de líneas de calidad por el efecto tractor que desempeñan sobre las producciones agrarias y ganaderas. 


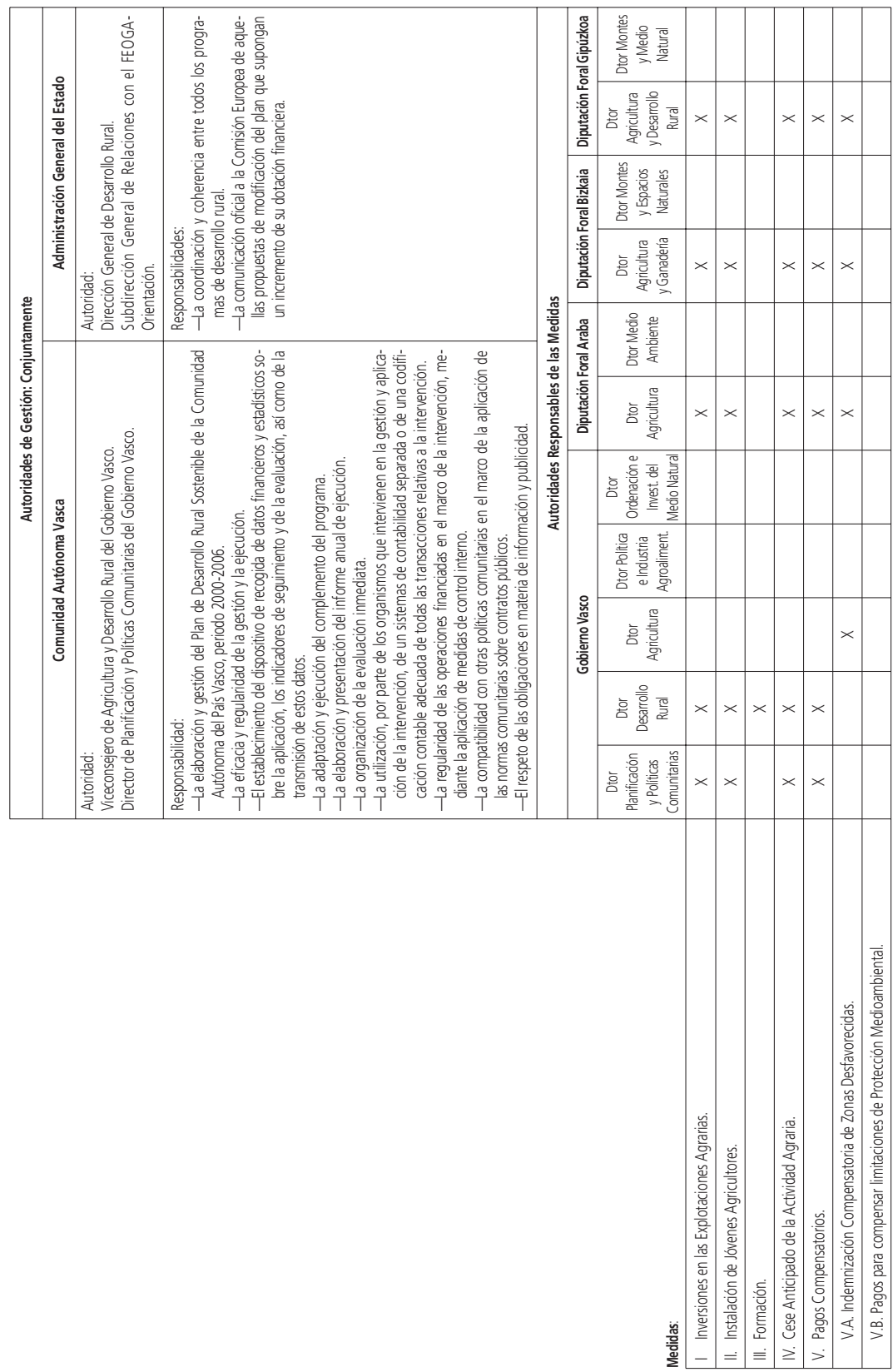

$(4 \pm)$ Asociación Internacional 


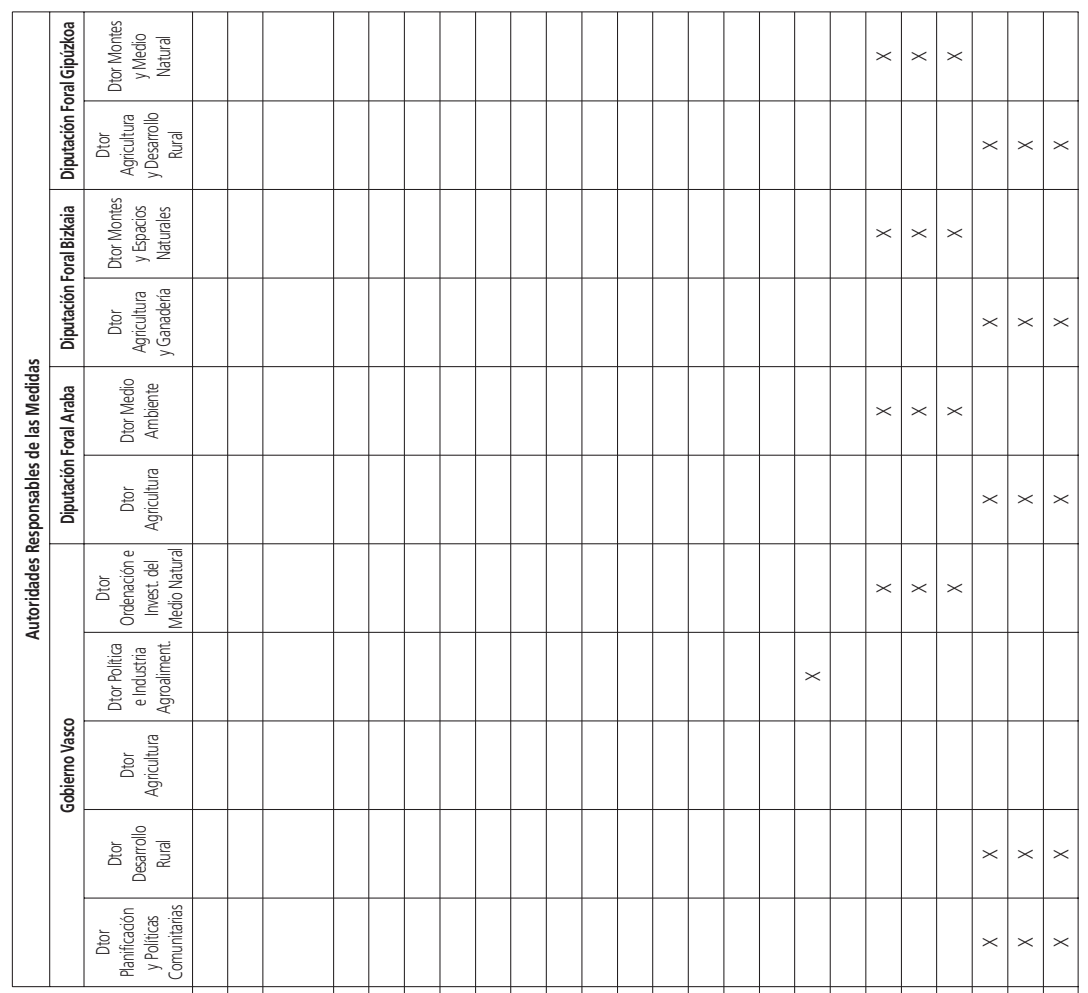

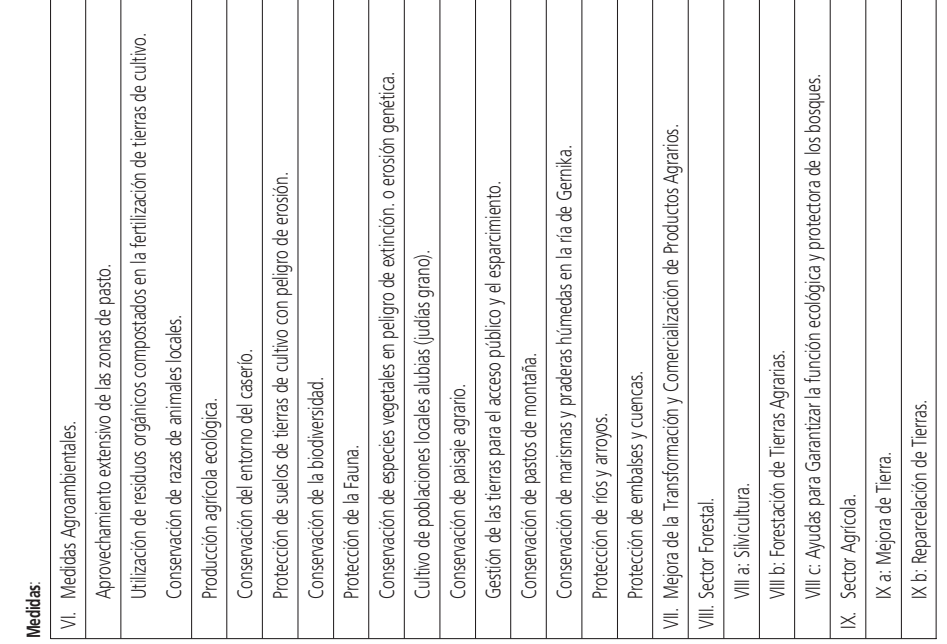




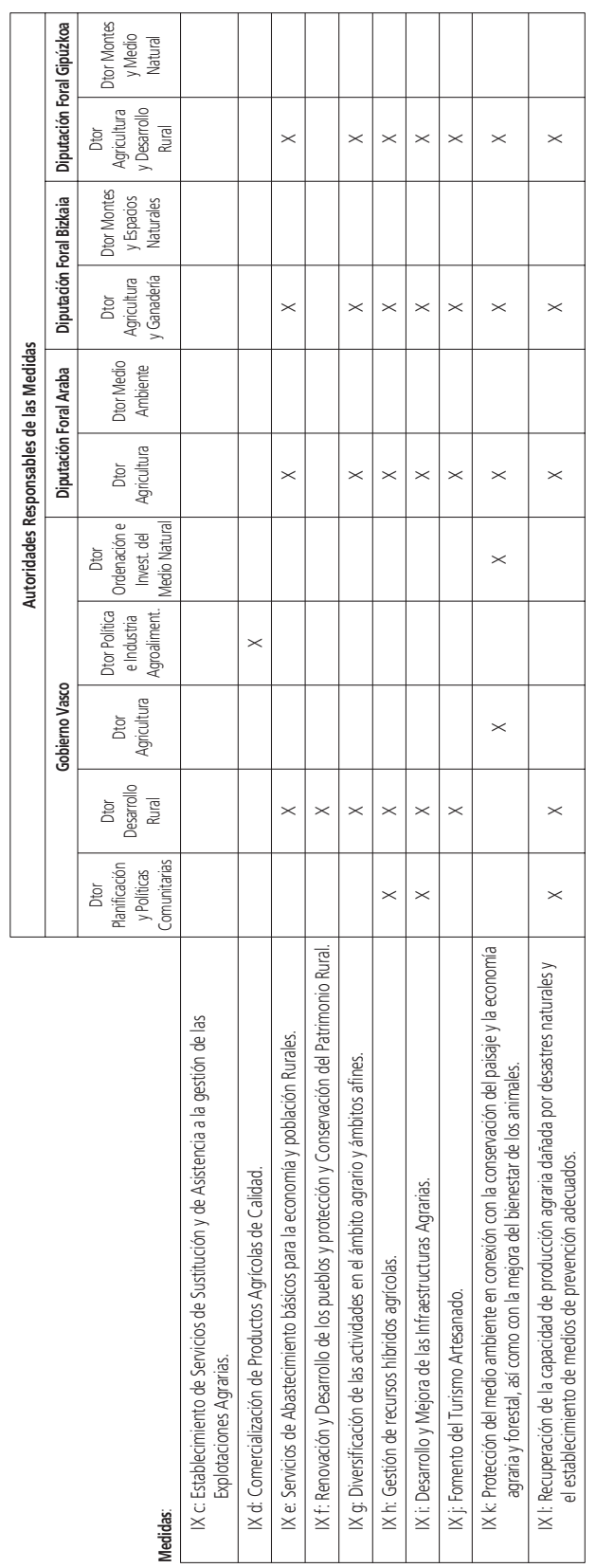

(AD) $\overline{\text { Asociación Internacional }}$ 
Ayudas Agroalimentarias.

A continuación expondré las principales ayudas aprobadas donde nos centraremos en las que tienen por objeto la pertenencia al sector agroalimentario y no aquellas otras en las que la concesión exige el cumplimiento individualizado de condiciones objetivas y subjetivas específicas para una determinada ayuda. Así mismo se incluyen las correspondientes al Plan de Ayuda al Sector Agrario de las Diputaciones, y finalmente aquellas ayudas directas a la producción correspondientes a los pagos compensatorios por cultivos herbáceos y primas ganaderas.

\begin{tabular}{|c|c|c|}
\hline Institución & Materia Objeto de Ayuda & Ayuda \\
\hline Gobierno Vasco & $\begin{array}{l}\text { Ayudas Agroambientales: fomento de } \\
\text { métodos de producción agraria com- } \\
\text { patibles con las exigencias de la pro- } \\
\text { tección del medio ambiente y conser- } \\
\text { vación de los recursos naturales. }\end{array}$ & $\begin{array}{l}\text { Diversas subvenciones di- } \\
\text { rectas. }\end{array}$ \\
\hline Gobierno Vasco & $\begin{array}{l}\text { PROGRAMA EGOKI } \\
\text { Ayudas a la mejora de las condicio- } \\
\text { nes de transformación y comerciali- } \\
\text { zación de los productos agrarios, } \\
\text { silvícolas, de la pesca y la acuicul- } \\
\text { tura y de la alimentación. }\end{array}$ & $\begin{array}{l}\text { Subvención directa del } 5 \% \\
\text { hasta } 10 \%-15 \% \text { y de par- } \\
\text { te del coste financiero. }\end{array}$ \\
\hline Gobierno Vasco & $\begin{array}{l}\text { Ayudas a la investigación e innova- } \\
\text { ción del sector agrario, agroalimen- } \\
\text { tario y pesquero de la C.A.V. }\end{array}$ & $\begin{array}{l}\text { Subvención directa de has- } \\
\text { ta } 50 \% \text { de los gastos en in- } \\
\text { vestigación... }\end{array}$ \\
\hline Gobierno Vasco & $\begin{array}{l}\text { PROGRAMA EKIN } \\
\text { Ayudas a la industria agropesquera } \\
\text { para la mejora de la calidad de sus } \\
\text { productos. }\end{array}$ & $\begin{array}{l}\text { Subvención directa de has- } \\
\text { ta } 50 \% \text { en proyectos de } \\
\text { diagnóstico y contratación } \\
\text { de servicios técnicos. }\end{array}$ \\
\hline Gobierno Vasco & $\begin{array}{l}\text { PROGRAMA EREIN } \\
\text { Ayudas a la promoción y Desarrollo } \\
\text { de las Zonas Rurales de la C.A.V. }\end{array}$ & $\begin{array}{l}\text { Ayuda directa de hasta } \\
25 \%-35 \%-80 \%-100 \% \\
\text { (formación profesional o ac- } \\
\text { ciones de entidades locales). }\end{array}$ \\
\hline $\begin{array}{l}\text { Diputaciones Fo- } \\
\text { rales (Ejemplo: } \\
\text { Diputación Foral } \\
\text { de Araba) }\end{array}$ & Plan de Ayudas al Sector Agrario. & $\begin{array}{l}\text { Subvención directa y pun- } \\
\text { tos de interés. }\end{array}$ \\
\hline Unión Europea & Agricultura. & $\begin{array}{l}\text { Pagos compensatorios por } \\
\text { Cultivos Herbáceos. }\end{array}$ \\
\hline Unión Europea & Primas Ganaderas. & $\begin{array}{l}\text { Primas de vacas nodrizas, } \\
\text { cebo, ovino-caprino. }\end{array}$ \\
\hline
\end{tabular}


Con objeto de materializar dichas ayudas, además de mecanismos como las subvenciones directas, hay ayudas en forma de subsidios de puntos de interés para lo cual las diversas administraciones públicas han firmado convenios de colaboración con las entidades financieras permitiendo a los diversos agentes del sector acceder a fuentes de financiación baratas.

Como una fórmula especial de subvención es la llamada EPSV de la Patata, cuya gestión está encomendada a la Caja y permite mediante aportaciones de la administración el sostenimiento primario de los precios de la patata.

Organismo: Departamento de Agricultura y Pesca.

Normativa: Decreto 213/2000 de 24 de octubre.

Orden de 5 marzo de 2002.

Objetivo:

Establecer en el ámbito de actuación de la CC.AA del País Vasco un régimen de ayudas para el fomento de métodos de producción agraria compatibles con las exigencias de la protección del medio ambiente y conservación de los recursos naturales, financiadas con cargo a los fondos FEOGA-Garantía y a los presupuestos generales de CAPV.

Las ayudas previstas de este decreto deberán ser objeto de desarrollo normativo por parte de las Diputaciones Forales, dentro del marco establecido en el presente decreto.

Este régimen de ayudas tiene por objetivos:

-Fomentar la utilización de técnicas de producción compatibles con la protección y mejora del medio ambiente, del paisaje y sus características, de los recursos naturales, del suelo y la diversidad genética.

- Fomentar una extensificación de la producción agraria que sea favorable para el medio ambiente y una gestión de sistemas de pastoreo de baja intensidad

- Conservar y mejorar los ecosistemas mediante la conservación y restauración de la vegetación natural, la protección del hábitat y su diversidad y utilización de prácticas agrarias que no perjudiquen la fauna.

- Conservar y mejorar los paisajes agrarios tradicionales, a través de la conversación de elementos singulares; Restauración de paisajes abandonados, prevención de incendios y mantenimiento de los sistemas agrarios tradicionales. 
- Sensibilizar y formar a los agricultores y a la sociedad en general en materia de producción agraria compatible con la protección del medio ambiente.

\section{Beneficiarios:}

1. Personas físicas y jurídicas que cumplan los requisitos especificados en cada uno de los regímenes de ayuda que se trate.

2. Cuando se establezca que los beneficiarios son los agricultores o titulares de la explotación agraria, éstos deberán cumplir los siguientes requisitos.

A En el caso de explotaciones familiares cuyo titular sean personas físicas:

- Ser titular o cotitular de una explotación agraria

—Estar al corriente de las obligaciones fiscales y de la seguridad social.

- Comprometerse a ejercer la actividad agraria en la explotación objeto de la ayuda durante al menos cinco años contados desde la fecha de la suscripción del correspondiente compromiso.

- Haber cumplido 18 años.

B/ En el caso de explotaciones asociativas cuyo titular sea una persona jurídica, al menos el $50 \%$ de sus miembros deberán reunir los requisitos exigidos a los titulares de explotaciones asociativas.

C/ A los efectos de la aplicación del presente decreto, las explotaciones agrarias que pertenezcan a una comunidad de bienes 0 hereditaria serán consideradas explotaciones asociativas.

3. Las diputaciones forales de los territorios históricos podrán imponer requisitos más estrictos relativos a los beneficiarios de las diversas líneas de ayudas en las que participen en su financiación.

\section{Ayudas:}

Las ayudas que se convocan son las siguientes:

- Ayuda al aprovechamiento extensivo de las zonas de pastos (praderas y pastizales).

- Ayuda para la protección de suelos en tierras de cultivo en peligro de erosión.

- Ayuda para la protección de la fauna.

- Ayuda para la conservación de especies vegetales en peligro de extinción o erosión genética.

—Ayuda para la formación y sensibilización agroambientales.

- Ayuda para la conservación del paisaje agrario.

- Ayuda para la conservación del entorno del caserío.

- Ayuda para la protección de embalses y cuencas. 
Plazos

Los plazos de presentación de solicitudes dependerán del territorio histórico donde esté registrada la explotación:

Alava: desde el día siguiente a la publicación de esta orden hasta el 30 de abril

Bizkaia y Gipuzkoa: desde el 15 de marzo hasta el 30 de abril.

\section{Solicitudes:}

Las solicitudes para acceder a estas ayudas deberán ser presentadas ante la Dirección de Agricultura.

\section{Ayudas a la mejora de las condiciones de transformación y comercialización de los productos agrarios, silvícolas, de la pesca y la acuicultura y de la alimentación. Programa EGOKI}

Organismo: Departamento de Agricultura y Pesca.

Normativa: Decreto 298/2000 de 26 de diciembre. Orden del 15 de marzo de 2002.

Objetivo:

Programa de ayuda a la mejora de las condiciones de transformación y comercialización de productos, agrarios, silvícolas de pesca y la acuicultura y de la alimentación.

\section{Beneficiarios:}

1. Podrán ser beneficiarios de las ayudas reguladas en el presente Decreto, las personas físicas o jurídicas que contraten y financien las inversiones y gastos que consideren subvencionables en el presente decreto y que realicen o vayan a desarrollar la actividad para la que se otorga la ayuda.

2. La actividad de comercialización tanto mayorista como minorista de productos agroalimentarios no será objeto del presente decreto. No obstante podrán ser objeto de los programas de ayuda regulados en el presente decreto, las actividades de transformación de productos agroalimentarios conexas al comercio mayorista o minorista, siempre que puedan acreditar suficientemente que al menos del $50 \%$ de la producción se destina a terceros. 
Ayuda:

1. Las inversiones y gastos que se consideran subvencionables, podrán ser subvencionados a fondo perdido en forma de ayuda directa.

2. Asimismo, las inversiones y gastos que se consideran subvencionables relativos a la mejora de la transformación y comercialización de productos agrarios y silvícolas, derivados de la pesca y acuicultura y que sean realizados por pequeñas y medianas empresas, podrán ser subvencionados en forma de ayuda a la reducción del coste financiero.

Esta modalidad de ayuda se refiere a las operaciones tanto de préstamo como de arrendamiento financiero a formalizar con las entidades financieras al amparo del presente decreto y convenio de colaboración suscrito ente las mismas y los Departamentos de Agricultura y Pesca y de administración pública del Gobierno Vasco con fecha 31 de mayo de 2000, de conformidad con las partes firmantes, o del contrato de financiación suscrito entre el instituto de crédito oficial y dichas entidades financieras, en el macro del protocolo de colaboración entre la CC.AA del País Vasco el instituto de crédito oficial. En tanto la entidad cuente con saldo en la línea abierta y disponible en la ICO, las operaciones a formalizar se adecuarán a las condiciones establecidas en dicha línea.

Asimismo, se refiere a las operaciones de préstamo y de arrendamiento financiero a formalizar al amparo de posibles convenios que pudieran concentrarse entre los departamentos citados y las entidades financieras, en base a las líneas de financiación comunitarias.

1. Ayuda base:

- Por los proyectos de inversión cuya solicitud sea aprobada, se establece como norma general una subvención base en forma de ayuda directa del $5 \%$ sobre el total de inversiones y gastos subvencionables.

2. Ayudas complementarias:

— La ayuda base en función de las disponibilidades presupuestarias existentes y de las solicitudes e inversiones subvencionables aceptadas, se podrá incrementar con los complementos siguientes, que además serán acumulativos.

- Las inversiones consideradas prioritarias podrán tener un incremento de subvención directa sobre la ayuda base de hasta un $15 \%$ pudiendo ser diferente en función necesidades y circunstancias concretas de cada sector.

- Las inversiones en empresas de nueva creación o las inversiones presentadas conjuntamente por varias empresas preexistentes de 
los sectores agroalimentarios subvencionables, podrán tener un incremento de subvención de hasta un 15\%.

- Las empresas existentes del sector conservero-pesquero y del sector de las industrias cárnicas que sean trasladadas fuera del casco urbano, podrán tener un incremento de subvención de hasta un $15 \%$.

- Las inversiones efectuadas por empresas en las que más de la mitad de su capital social esté distribuido entre productores del sector primario, bajo cualquier forma jurídica de asociación de los mismos podrán tener un incremento de subvención de hasta un $10 \%$ y hasta un $15 \%$ bajo la forma jurídica de cooperativa.

- Las inversiones orientadas a la protección del medio ambiente o la prevención de la contaminación, podrán tener un incremento de subvención de hasta un $10 \%$.

- las inversiones destinadas a la obtención de productos con distintivos de calidad, podrán tener un incremento de subvención de hasta un $10 \%$

- Las inversiones presentadas por las empresas para la adaptación a nuevas normativas técnico sanitarias, podrán tener un incremento de subvención de hasta un 10\%.

- En cualquier caso y en función de las solicitudes presentadas, del valor estratégico de la acción propuesta y el volumen total de inversiones subvencionables, se podrá alcanzar el porcentaje máximo subvencionable.

\section{Plazo:}

Anualmente, por orden del consejero de Agricultura y Pesca, se abrirá el plazo de presentación de solicitudes. No obstante, se entenderán presentadas dentro de plazo aquellos proyectos que sean susceptibles de financiación comunitaria, y cuya solicitud se haya realizado a partir del 1 de enero de 2002. El plazo también será de un mes desde el día siguiente de la publicación de dicha orden.

\section{Solicitudes}

Las solicitudes de ayuda se presentarán bien en las dependencias de la Dirección de Política e Industria Agroalimentaria sita en la calle DonostiaSan Sebastián n. ${ }^{\circ} 1$ de Vitoria-Gazteiz, o bien en por cualquiera de los medios previstos en el artículo 38.4 de la Ley del Régimen Jurídico de las Administraciones Públicas y del Procedimiento Administrativo Común, y se regirán al Director de Política e Industria Agroalimentaria. 


\section{Ayudas a la investigación e innovación \\ del Sector Agrario, Agroalimentario y Pesquero de la CAV}

Organismo: Departamento de Agricultura y Pesca.

Normativa: Decreto 367/1995 de 11 de julio

Orden de 19 de septiembre de 2002.

\section{Objetivo}

Establecer el marco de ayudas de la administración general de comunidad autónoma del País Vasco dirigidas a estimular e incentivar la realización de proyectos y actividades de investigación y desarrollo tecnológico y experimental en los sectores agrario, agroalimentario y pesquero, realizados en la comunidad autónoma del País Vasco.

\section{Beneficiarios}

1. Las empresas agrarias, agroalimentarias y pesqueras, domiciliadas en Comunidad Autónoma del País Vasco cuando actúen en colaboración con centros oficiales de investigación o departamentos universitarios.

2. Las empresas agrarias agroalimentarias y pesqueras domiciliadas en la comunidad autónoma del País Vasco con I+D propio.

A los efectos de esta orden, se considerarán centros de I+D propios, aquellas unidades independientes que realicen o van a realizar actividades de I+D de forma permanente y que dispongan de activos y estructura adecuada para su desarrollo y realización, de manera que su existencia o su creación pueda ser demostrada de forma inequívoca. En todo caso el departamento de Agricultura y Pesca podrá realizar cuantas comprobaciones estime necesarias a dichos efectos, con carácter previo a la resolución de las solicitudes presentadas.

3. Las asociaciones y agrupaciones de empresas del sector agrario, agroalimentario y pesquero, domiciliadas en la comunidad autónoma del País Vasco, constituidas para la realización de alguna de las actividades a que se dediquen a la elaboración de productos o procesos de producción nuevos o perfeccionados sustancialmente hasta la fase no incluida de aplicación industrial explotación comercial, que actúen en colaboración con un centro de I+D de alguno de sus miembros o con uno o varios centros de investigación o centros universitarios.

4. Empresas de capital público o privado cuya actividad principal sea la investigación en sectores agrario agroalimentario o pesquero. 


\section{Ayudas}

1. Para actividades de investigación básica (actividad teórica y experimental original cuyo objetivo es la adquisición de nuevos conocimientos para su aplicación eventual a un subsector agrario o pesquero) las ayudas podrán alcanzar has el $50 \%$ de los gastos que facturen las empresas y entidades que sean admitidas como beneficiarios de acuerdo al presupuesto aprobado por el departamento de Agricultura y Pesca con un máximo de 48.080,97 euros.

2. Para actividades de investigación aplicada (que cubre los trabajos de investigación o experimentación que basados en la investigación básica, se realizan para adquirir nuevos conocimientos que faciliten la materialización de objetivos prácticos específicos tales como la creación de nuevos productos) innovación (como acción permanente en la búsqueda de modificaciones y cambios significativos conducentes a satisfacer las necesidades del mercado y a la mejora de la competitividad industrial) desarrollo (incluye la transferencia de tecnología así como los proyectos piloto que desembocan en un conjunto de informaciones que permite el paso a la fase de producción las ayudas podrán alcanzar el $25 \%$ de los gastos que facturen dichas empresas y entidades de acuerdo al presupuesto aprobado por el Departamento de Agricultura y Pesca con un límite máximo de 48.080,97 euros de subvención).

3. El nivel de ayuda establecido en los apartados anteriores podrán incrementarse en un 10\% cuando se trate de ayudas destinadas a pequeña y mediana empresa.

\section{Plazo}

Un mes a partir del día siguiente de la de la publicación de la presente orden en el Boletín Oficial del País Vasco.

\section{Solicitud}

Dirección de investigación

Departamento de Agricultura y Pesca

Gobierno Vasco

C/ Donostia-San Sebastián, 1

01010 Vitoria-Gasteiz 


\section{Ayudas a la Industria Agropesquera para la mejora de la calidad de sus productos. Programa EKIN}

Organismo: Departamento Agricultura y Pesca.

Normativa: Decreto 165/2000 de 28 de julio. Orden de 16 de mayo de 2002.

Objetivo:

Dicho decreto tiene como objeto la regulación del programa de ayudas para fomentar las inversiones o gastos que tengan como objetivo, el diagnóstico, asesoramiento y/o implantación de sistemas de aseguramiento de la calidad en aquellas industrias agropesqueras que estén incluidas dentro del ámbito competencial del Departamento de Agricultura y Pesca del Gobierno Vasco.

\section{Beneficiarios:}

Podrán ser beneficiarios de las ayudas previstas, las industrias agropesqueras que realicen inversiones en la Comunidad Autónoma del País Vasco, independientemente del territorio donde se ubique su domicilio o sede social, y cumplan los requisitos establecidos.

\section{Ayudas:}

1. Para la realización de estudios de diagnóstico de calidad (se establecen ayudas para las empresas que contraten la realización de proyectos, estudios o informes acerca de sus sistemas de calidad) las ayudas consistirán en subvenciones directas de hasta un 50\% del coste de la realización de los citados proyectos, estudios e informes.

2. En inversiones para el aseguramiento de la calidad (se establecen ayudas para la realización de aquellas inversiones nuevas relacionadas con la gestión de calidad), que los estudios mencionados en el párrafo anterior hayan considerado necesarias para la implantación de un sistema de aseguramiento de calidad.

3. Para la contratación de servicios técnicos (se establecen ayudas para la contratación de servicios técnicos con la finalidad de tecnificar los sistemas de aseguramiento de la calidad), las ayudas consistirán en subvenciones directas de hasta un $50 \%$ del coste de contratación de los servicios.

\section{Plazo}

Un mes desde el día siguiente a la publicación de la presente orden en el Boletín Oficial del País Vasco. 


\section{Ayudas a la Promoción y Desarrollo de las Zonas Rurales de la CAV. Programa EREIN}

Organismo: Departamento Agricultura y Pesca.

Normativa: Decreto 100/2002 de 7 de mayo.

Objetivo:

Recoger y regular la concesión de ayudas económicas destinadas a la financiación de actividades e inversiones de promoción y desarrollo, en las zonas rurales de la Comunidad autónoma del País Vasco. Tales ayudas se identifican bajo la denominación de Programa Erein.

\section{Beneficiarios:}

1. Podrán resultar personas beneficiarias de las ayudas reguladas en el presente Decreto las personas físicas, las personas jurídico-privadas con o sin ánimo de lucro, así como entidades locales, Entes públicos de carácter local, Corporaciones de derecho público y cualquier otra forma jurídica recogida en la legislación vigente que cumplan, además de los requisitos señalados en cada modalidad de ayuda, los siguientes requisitos:
A/ Realizar alguna de las actividades auxiliables dentro de alguna de las zonas previstas.
B/ En el caso de empresas, los solicitantes deberán tener la considera- ción de pequeña o mediana empresa.
C/ Estar al corriente de sus obligaciones tributarias y de la Seguridad Social.

2. En caso de ayudas solicitadas para la puesta en marcha de una empresa, bajo cualquier modalidad de entidad personificada, tendrá la consideración de beneficiario la entidad que se constituya para su gestión, actuando como solicitante quien ostente la representación legal de la misma de manera debidamente justificada.

\section{Ayuda:}

1. Las ayudas que se concedan en virtud del presente decreto tendrán la consideración de subvenciones no reintegrables.

2. Este decreto recoge las siguientes modalidades de ayudas: - Ayudas confinadas por el FEOGA.

1. En el caso de inversiones productivas en Pymes la intensidad de la ayuda podrá alcanzar un máximo del $25 \%$ del coste total subvencionable y en zonas rurales en declive o con problemas estructurales hasta el $35 \%$.

2. En el caso de inversiones no productivas realizadas por particulares la intensidad de ayuda podrá alcanzar un máximo del $80 \%$.

3. Para formación profesional agraria la ayuda pública podrá alcanzar hasta el $100 \%$ del coste total subvencionable. 
4. Si la acción se realiza por entidades locales o entes públicos de carácter local sin ánimo de lucro, la ayuda podrá alcanzar el $100 \%$ del coste total subvencionable.

-Ayudas a las infraestructuras y desarrollo económico en zonas rurales.

1. En el caso de inversiones productivas en Pymes la intensidad de la ayuda podrá alcanzar un máximo del $25 \%$ del coste total subvencionable y en zonas rurales en declive o con problemas estructurales hasta el 35\%.

2. En el caso de inversiones no productivas realizadas por particulares la intensidad de ayuda podrá alcanzar un máximo del $80 \%$.

3. Si la acción se realiza por entidades locales o entes públicos de carácter local sin ánimo de lucro, la ayuda podrá alcanzar el $100 \%$ del coste total subvencionable.

—Ayudas al empleo en las zonas rurales.

1. Ayudas a la creación de empleo ligadas a la inversión; la ayuda máxima que se concederá por puesto de trabajo que cree una empresa será de 4.500 euros y hasta 6.000 en caso de parados de larga duración, mujeres con cargas familiares o minusválidos siempre que se efectúe dicha contratación durante un periodo mínimo de 3 años y debiendo mantenerse el puesto creado durante al menos dos años más. En todo caso, dichas ayudas no podrán rebasar el 35\% del salario bruto correspondiente a dos años de la persona contratada, es decir, antes de impuestos y de las cotizaciones sociales obligatorias.

2. Ayudas a la creación de empleo no ligadas a la inversión; (ídem al punto anterior).

3. Los recursos económicos destinados a esta finalidad procederán de los fondos de FEOGA-GARANTÍA y de los correspondientes créditos establecidos al efecto en los presupuestos generales de la CC.AA del País Vasco para cada ejercicio.

4. Las ayudas aquí establecidas se irán concediendo conforme se vayan solicitando y se complete cada expediente y siempre que se cumpla el resto de los requisitos establecidos en el presente Decreto.

\section{Plazo}

El consejero de Agricultura y Pesca abrirá el plazo para la concesión de dichas ayudas, se admitirán las solicitudes presentadas anualmente con anterioridad a la apertura del plazo.

\section{Solicitudes}

Las solicitudes para acogerse a las ayudas establecidas en este decreto se presentarán en la Entidad colaboradora (Sociedad pública Mendikoi.A, B), bien directamente o bien a través de las asociaciones de Agricultura de Montaña y asociaciones de desarrollo rural, adjuntando la documentación correspondiente. 


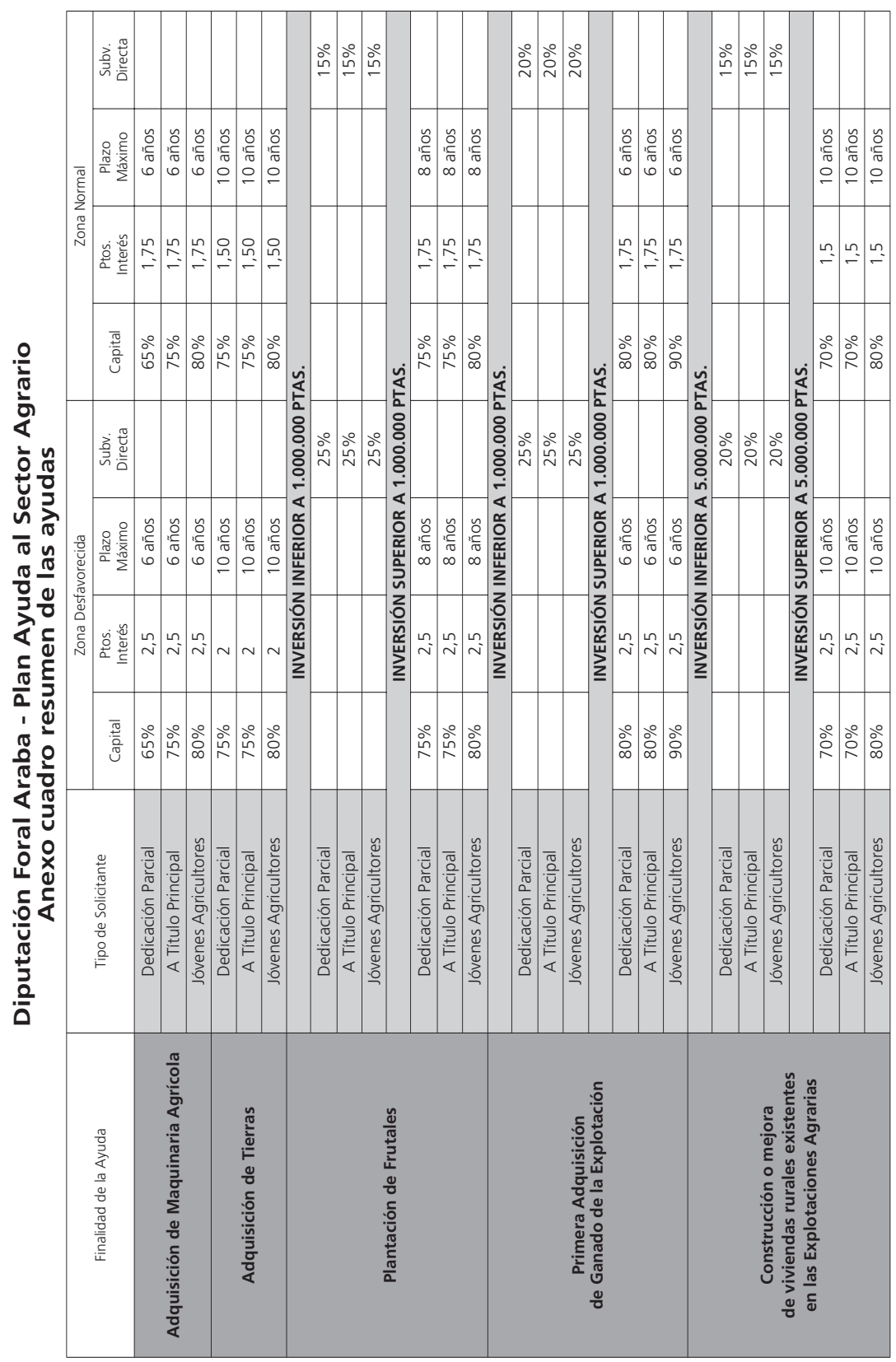

(4⿻) $\overline{\text { Asociación Internacional }}$ 


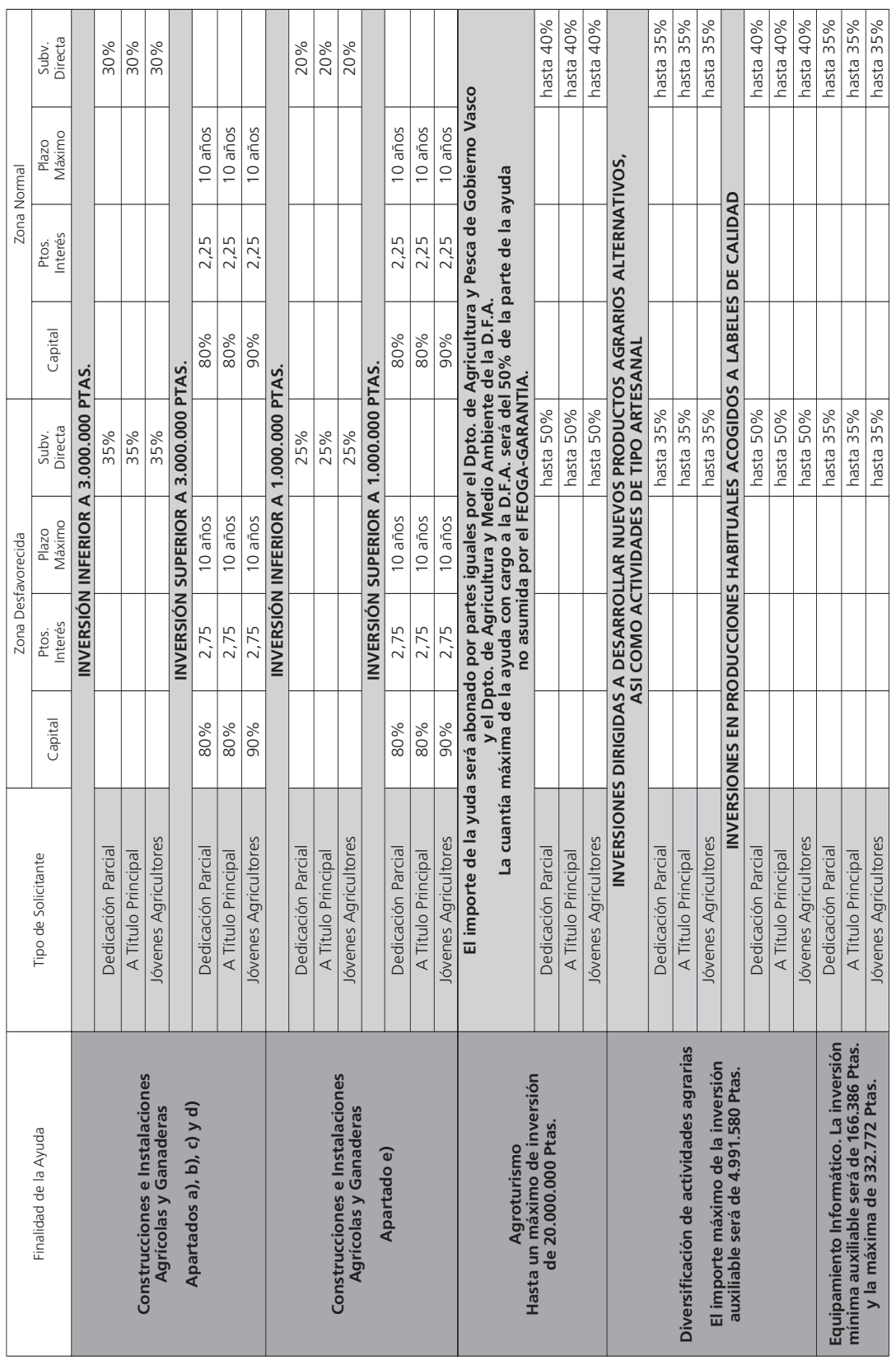




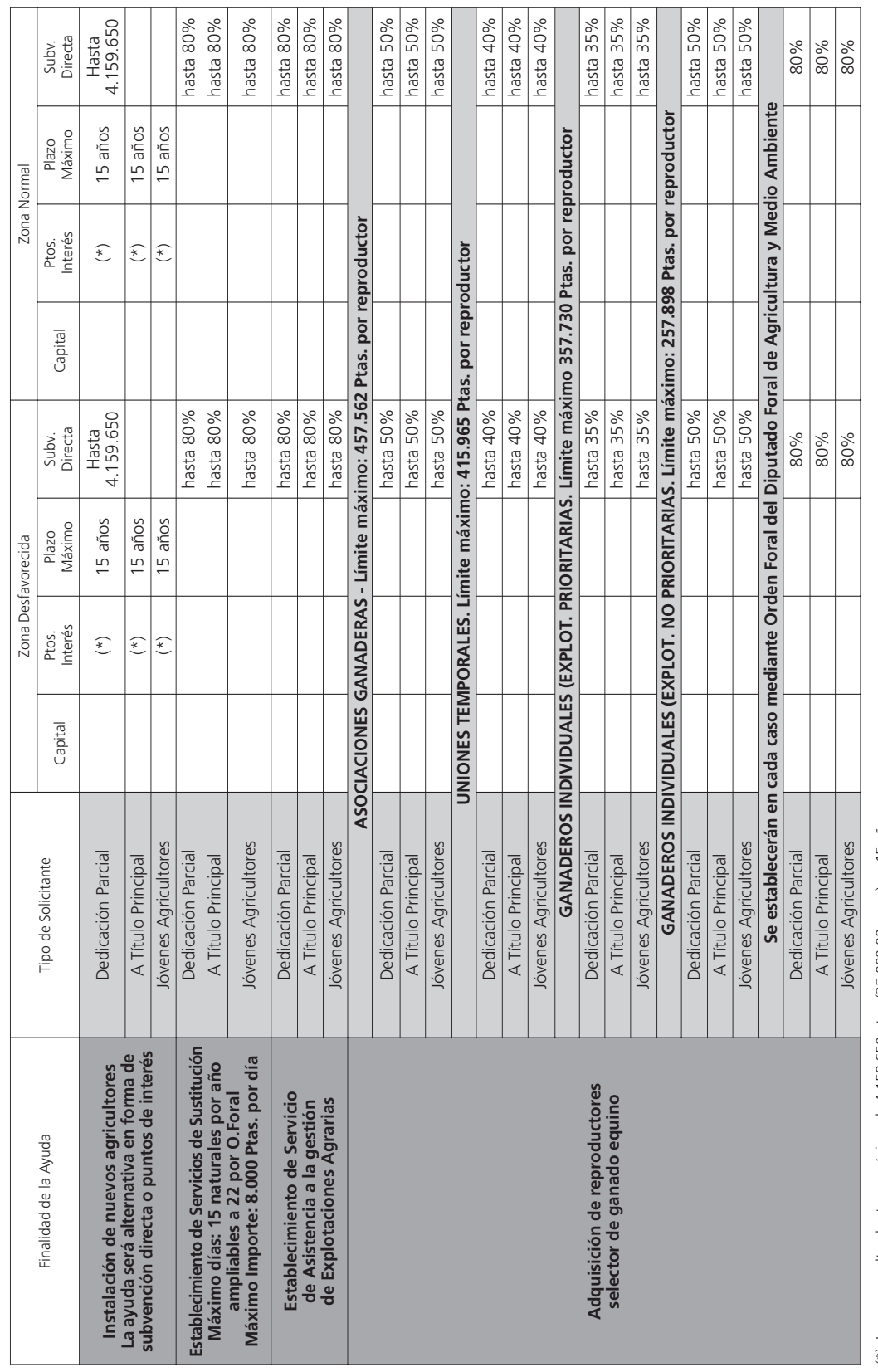

(AD) $\overline{\text { Asociación Internacional }}$ 


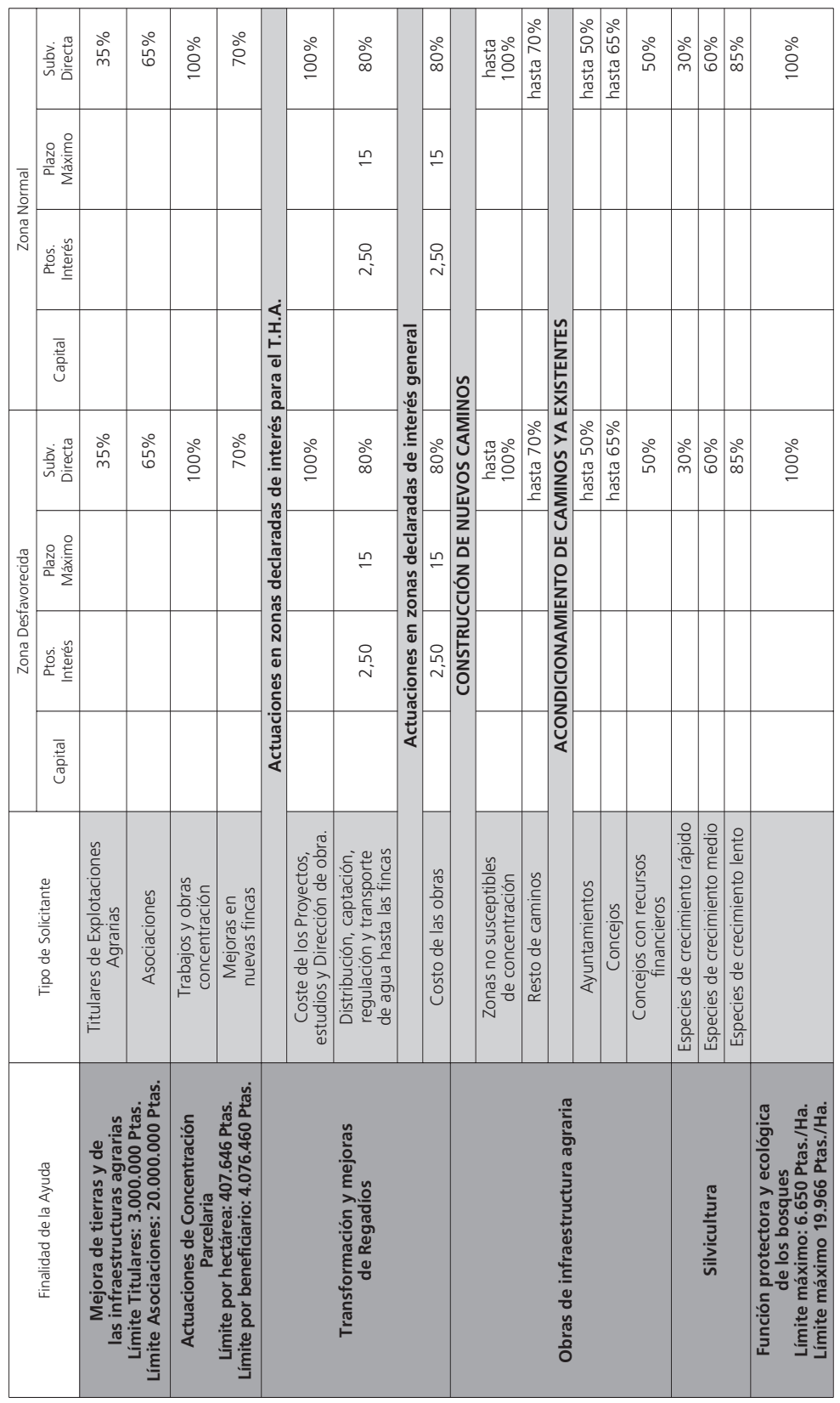




\section{PAC 2002 \\ Ayudas de cultivos herbáceos}

\begin{tabular}{|c|c|c|c|c|c|c|}
\hline \multicolumn{7}{|c|}{ Rendimientos en cultivos herbáceos (Tm/ha. Región: 4,4 Tm/ha) } \\
\hline \multirow{3}{*}{$\begin{array}{l}\text { Año de } \\
\text { siembra }\end{array}$} & \multirow{3}{*}{$\begin{array}{c}\text { Secano } \\
\text { Todos los cultivos }\end{array}$} & \multicolumn{5}{|c|}{ Regadío } \\
\hline & & \multicolumn{2}{|c|}{ Rdmto. Medio } & \multirow[b]{2}{*}{ Maíz } & \multicolumn{2}{|c|}{ Otros Cereales } \\
\hline & & $\begin{array}{l}\text { Proteaginosas } \\
\text { Retirada }\end{array}$ & Oleaginosas & & Cereal, Lino & Oleaginosas \\
\hline 1999-00 & 4,4 & 8,1 & 8,1 & 8,5 & 4,6 & - \\
\hline 2000-01 & 4,4 & 8,1 & 8,1 & 8,5 & 4,6 & - \\
\hline 2001-02 & 4,4 & 8,1 & - & 8,5 & \multicolumn{2}{|c|}{4,6} \\
\hline 2002-03 & 4,4 & 8,1 & - & 8,5 & \multicolumn{2}{|c|}{4,6} \\
\hline 2003-04 & 4,4 & 8,1 & - & 8,5 & \multicolumn{2}{|c|}{4,6} \\
\hline 2004-05 & 4,4 & 8,1 & - & 8,5 & \multicolumn{2}{|c|}{4,6} \\
\hline 2005-06 & 4,4 & 8,1 & - & 8,5 & \multicolumn{2}{|c|}{4,6} \\
\hline
\end{tabular}

\begin{tabular}{|c|c|c|c|c|c|c|c|c|}
\hline \multicolumn{7}{|c|}{ Pagos compensatorios (Ptas./ha. 4,4 Tm/ha) } \\
\hline \multirow{2}{*}{$\begin{array}{c}\text { Año de } \\
\text { siembra }\end{array}$} & \multicolumn{3}{|c|}{ Secano } & \multicolumn{3}{c|}{ Rdmto. Medio } & \multirow{2}{*}{ Máiz } & $\begin{array}{c}\text { Otros } \\
\text { Cereales }\end{array}$ \\
\cline { 2 - 6 } & $\begin{array}{c}\text { Cereal } \\
\text { Retirada }\end{array}$ & Proteaginosas & Oleaginosas & Proteaginosas & Retirada & Oleaginosa & & \\
\hline $1999-00$ & 42.952 & 53.077 & 59.842 & 97.710 & 79.071 & 110.163 & 82.976 & 44.905 \\
$\mathbf{2 0 0 0 - 0 1}$ & $\mathbf{4 6 . 1 2 2}$ & $\mathbf{5 3 . 0 7 7}$ & $\mathbf{5 2 . 9 8 2}$ & $\mathbf{9 7 . 7 1 0}$ & $\mathbf{8 4 . 9 0 7}$ & $\mathbf{9 7 . 5 3 5}$ & $\mathbf{8 9 . 1 0 0}$ & $\mathbf{4 8 . 2 1 9}$ \\
$2001-02$ & 46.122 & 53.077 & 46.122 & 97.710 & 84.907 & 48.219 & 89.100 & 48.219 \\
$2002-03$ & 46.122 & 53.077 & 46.122 & 97.710 & 84.907 & 48.219 & 89.100 & 48.219 \\
$2003-04$ & 46.122 & 53.077 & 46.122 & 97.710 & 84.907 & 48.219 & 89.100 & 48.219 \\
$2004-05$ & 46.122 & 53.077 & 46.122 & 97.710 & 84.907 & 48.219 & 89.100 & 48.219 \\
$2005-06$ & 46.122 & 53.077 & 46.122 & 97.710 & 84.907 & 48.219 & 89.100 & 48.219 \\
\hline
\end{tabular}

\begin{tabular}{|c|c|c|}
\hline Cultivos herbáceos & Cambios en ayudas directas & Cambios en ayudas directas \\
\hline $\begin{array}{l}\text { - Se fija el período que va des- } \\
\text { de las campañas de siembra } \\
1999 / 2000 \text { a la } 2005 / 2006 \\
\text { — El precio de intervención de } \\
\text { los cereales se reduce en un } \\
15 \% \text { (de } 20 \text { a } 17 \text { ptas./kg). } \\
\text { Apartir de la campaña de } \\
\text { siembre } 2000 / 20001 \text { se fija } \\
\text { en } 17 \text { ptas./kg. } \\
\text { — Podría decidirse una reduc- } \\
\text { ción adicional del precio de } \\
\text { intervención, en función del } \\
\text { mercado, a partir de la cam- } \\
\text { paña de siembra 2001/2002. }\end{array}$ & $\begin{array}{l}\text { - Aumentan las ayudas direc- } \\
\text { tas a los cereales ( } 50 \% \text { com- } \\
\text { pensación intervención) } \\
\text { — A partir de la campaña de } \\
\text { siembra } 2000 / 2001 \text {, la ayuda } \\
\text { al cereal se estabiliza en } \\
10.482 \text { ptas/Tm. } \\
\text { — A partir de la campaña de } \\
\text { siembra 2001/2002 las ayu- } \\
\text { das a las oleaginosas se igua- } \\
\text { lan al cereal } \\
\text { — Se fija para todo el perío- } \\
\text { do (Campañas de siembra } \\
\text { 1999/2000 a 2005/2006) un } \\
\text { precio de } 12.063 \text { ptas./Tm. } \\
\text { de ayuda a los proteaginosas }\end{array}$ & $\begin{array}{l}\text { - A partir de esta campaña, la } \\
\text { ayuda a la retirada = Cereal } \\
\text { _ Los pagos específicos para } \\
\text { las oleaginosas, proteagino- } \\
\text { sas y lino no textil son tam- } \\
\text { bién accesibles a los peque- } \\
\text { ños productores ( } \leq 92 \mathrm{Tm} \text { ). } \\
\text { _ Período de pagos: } 16 \text { de no- } \\
\text { viembre - } 31 \text { enero siguiente } \\
\text { a la cosecha, incluidas olea- } \\
\text { ginosas, que se pagan de } \\
\text { una sola vez. } \\
\text { — Período de pagos en las reti- } \\
\text { radas no alimentarias: } 16 \text { de } \\
\text { noviembre - } 31 \text { de marzo si- } \\
\text { guiente a la cosecha. }\end{array}$ \\
\hline
\end{tabular}




\begin{tabular}{|c|c|c|c|c|}
\hline \multirow{2}{*}{\multicolumn{4}{|c|}{$\begin{array}{c}\text { Cultivos herbáceos } \\
\text { Pagos Compensatorios por Tonelada (Ptas.) } \\
\text { — En función de las campañas de siembra. }\end{array}$}} & \multirow{9}{*}{$\begin{array}{l}\text { Regionalización productiva } \\
\text { — Se contempla el secano y el regadío. En secano } \\
\text { un mismo rendimiento para todos los cultivos } \\
\text { en una misma región (Ejemplo: 4,4 Tm./Ha.) } \\
\text { — Tres rendimientos en regadío: } \\
\text { - Rendimiento medio (Proteaginosas, Retirada, } \\
\text { oleaginosas campañas de siembra 1999/2000 } \\
\text { y 2000/2001) 8,1 Tm. } \\
\text { - Rendimiento del maíz. 8,5 Tm. } \\
\text { - Otros cereales distintos al Maíz: Resto cerea- } \\
\text { les, lino no textil, oleaginosas a partir cam- } \\
\text { paña de siembre 2001/2002. 4,6 Tm. }\end{array}$} \\
\hline & & & & \\
\hline & 1999/2000 & 2000/2001 & $\begin{array}{c}\text { A partir } \\
2001 / 2002\end{array}$ & \\
\hline Cereales & $9.761,87$ & $10.482,32$ & $10.482,32$ & \\
\hline Proteaginosas & $12.062,98$ & $12.062,98$ & $12.062,98$ & \\
\hline Oleaginosas & $13.600,39$ & $12.041,35$ & $10.482,32$ & \\
\hline Retirada & $9.761,87$ & $10.482,32$ & $10.482,32$ & \\
\hline Lino no textil & $14.685,23$ & $12.583,77$ & $10.482,32$ & \\
\hline & & & & \\
\hline
\end{tabular}

\section{Unión Europea - Primas Ganaderas Pagos por Primas Ganaderas 2002-2006}

Prima de vacas nodrizas: Período de retención: 6 meses

Prima de cebo: $\quad$ Toros: $>7$ meses

Período de retención: 2 meses

Bueyes: No se crían en Alava por falta de valor comercial

Prima de ovino - caprino: Prima en Zonas desfavorecidas: > 50\% de la S.A.U. agrícola en Zona desfavorecida.

Prima adicional: $\quad$ Según criterios y presupuesto anual de G.V.: En 2001: 6.000 - 10.000 ptas./ cabeza según baremo.

\begin{tabular}{|c|c|c|c|c|c|c|}
\hline \multicolumn{7}{|c|}{ Cuadro resumen (Euros / cabeza y año) } \\
\hline $\begin{array}{l}\text { Nombre } \\
\text { de } \\
\text { prima }\end{array}$ & Ganado & $\begin{array}{c}\text { Prima } \\
\text { Básica } \\
(<1,8 \text { UGM/ha) }\end{array}$ & $\begin{array}{c}\text { Prima } \\
\text { extensificación } \\
\text { (<1,4 UGM/ha) }\end{array}$ & $\begin{array}{c}\text { Prima } \\
\text { adicional } \\
\text { (A.T.P. / Label / Fechas parto) }\end{array}$ & Total & $\begin{array}{l}\text { Cupos o } \\
\text { reducciones } \\
\text { de ayuda }\end{array}$ \\
\hline $\begin{array}{l}\text { Vaca } \\
\text { nodriza }\end{array}$ & $\begin{array}{c}\text { Vacas } \\
\text { nodrizas }\end{array}$ & 200 & 100 & Criterio G.V. & $300+$ P.Adic. & $\begin{array}{l}\text { Según } \\
\text { derechos }\end{array}$ \\
\hline Cebo & Toro & 210 & 100 & Criterio G.V. & $310+$ P.Adic. & $\begin{array}{l}\text { Cupo: En } 2000 \\
\text { reducción: } 35 \%\end{array}$ \\
\hline \multirow{2}{*}{ Sacrificio } & $\begin{array}{l}\text { Bovino }> \\
8 \text { meses }\end{array}$ & 80 & NO & NO & 80 & \multirow{2}{*}{$\begin{array}{c}\text { Cupo: No ha habido } \\
\text { sobrepasamiento }\end{array}$} \\
\hline & $\begin{array}{c}\text { Bovino }>1 \text { mes } \\
<7 \text { meses }\end{array}$ & 50 & NO & NO & 50 & \\
\hline
\end{tabular}




\begin{tabular}{|c|c|c|c|c|c|c|}
\hline \multicolumn{7}{|c|}{ Ovino-Caprino } \\
\hline $\begin{array}{c}\text { Nombre } \\
\text { de } \\
\text { prima }\end{array}$ & Tipo ganado & Zona normal & Zona Montaña & $\begin{array}{c}\text { Zona de } \\
\text { Montaña y } \\
\text { desfavorecida }\end{array}$ & Total & $\begin{array}{l}\text { Cuposo } \\
\text { reducciones } \\
\text { de ayuda }\end{array}$ \\
\hline \multirow{3}{*}{$\begin{array}{l}\text { Ovino } \\
\text { caprino }\end{array}$} & $\begin{array}{c}\text { Oveja cordero } \\
\text { asado }\end{array}$ & 21 & & 7 & 28 & Según derechos \\
\hline & $\begin{array}{c}\text { Ovejas cordero } \\
\text { ligero }\end{array}$ & 16,8 & 7 & 7 & 23,8 & Según derechos \\
\hline & Caprino & NO & $16,8+7$ & - & 23,8 & Según derechos \\
\hline
\end{tabular}

La carga máxima para poder percibir la prima por vacas nodrizas y la prima especial de cebo, establecida en $2 \mathrm{UGM} / \mathrm{Ha}$ forrajera, se reduce en 1,90 en 2002 y a 1,8 en 2003.

Periodo 2000-2006

Pagos Primas Ganaderas

\begin{tabular}{|c|c|c|c|c|c|}
\hline \multirow{2}{*}{ Campaña } & \multicolumn{2}{|c|}{ Prima Especial } & \multirow{2}{*}{ Prima Vaca } & \multicolumn{2}{|c|}{ Prima por Sacrificio } \\
\cline { 2 - 3 } & Toro & Buey / tramo & Nodriza & $\begin{array}{c}\text { Bovinos }> \\
8 \text { meses }\end{array}$ & $\begin{array}{c}\text { mes < Bovinos } \\
<7 \text { meses }\end{array}$ \\
\hline 2000 & 26.622 & 20.299 & 27.121 & 4.492 & 2.829 \\
2001 & 30.781 & 22.628 & 30.282 & 8.818 & 5.491 \\
2002 y ss & 34.941 & 24.958 & 33.277 & 13.311 & 8.319 \\
\hline
\end{tabular}

Pagos Primas Extensificación

\begin{tabular}{|c|c|}
\hline Campaña & $\begin{array}{c}\text { Modalidad A } \\
\text { UGM/Ha }<=1,4\end{array}$ \\
\hline 2000 & 16.639 \\
2001 & 16.639 \\
2002 y ss & 16.639 \\
\hline
\end{tabular}




\section{B.2.3. Entidades de Apoyo al Sector Agroalimentario}

(Prestación de servicios en el campo del asesoramiento, de la formación o del intercambio empresarial.)

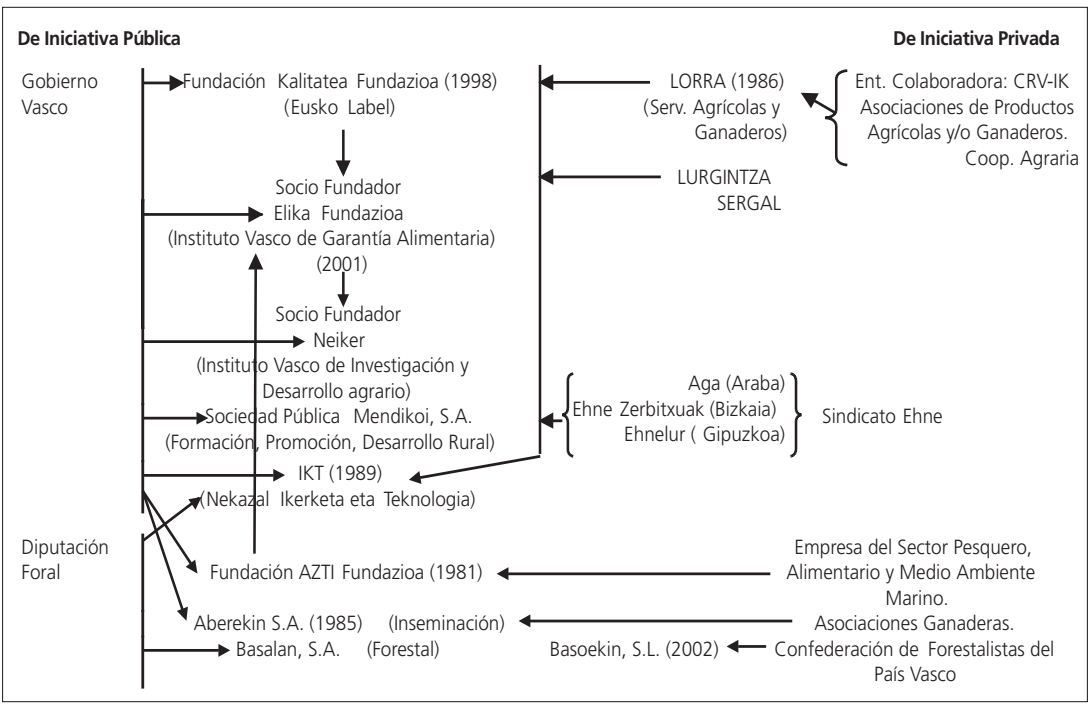

\begin{tabular}{||l|l|l||}
\hline \multicolumn{1}{|c|}{ Entidad } & \multicolumn{1}{|c|}{ Promotor } & \multicolumn{1}{c|}{ Función - Misión } \\
\hline $\begin{array}{l}\text { Fundación Kalitatea Fun- } \\
\text { dazioa } \\
\text { (Eusko Label) }\end{array}$ & $\begin{array}{l}\text { Gobierno Vasco } \\
\text { Dpto. Agricultura y Pesca } \\
1998\end{array}$ & $\begin{array}{l}\text { Impulsar, promover y desarrollar los pro- } \\
\text { ductos agroalimentarios de calidad, a } \\
\text { través de mecanismos que sirvan para } \\
\text { que dichos productos sean valorizados, } \\
\text { diferenciados y apreciados en el merca- } \\
\text { do, con el fin de conseguir un diferen- } \\
\text { cial competitivo con ello. } \\
\text { www.euskolabel.net }\end{array}$ \\
\hline $\begin{array}{l}\text { Elika Fundazioa } \\
\text { (Instituto Vasco de Ga- } \\
\text { rantía Alimentaria) }\end{array}$ & $\begin{array}{l}\text { Iniciativa: } \\
\text {-Gobierno Vasco - Dpto. } \\
\text { Agricultura y Pesca } \\
\text { (2001) } \\
\text { Socios Fundadores: } \\
\text { - Sociedad Pública Neiker. } \\
\text { - Fundación Kalitatea. } \\
\text { - Fundación AZTI Funda- } \\
\text { zioa. }\end{array}$ & $\begin{array}{l}\text { Contribuir a lograr un nivel alto de ga- } \\
\text { rantías de los productos agroalimenta- } \\
\text { rios la CAV desde el punto de vista } \\
\text { Reforzar y mantener la confianza de los } \\
\text { consumidores en los alimentos produci- } \\
\text { dos y/o elaborados en el País Vasco (Ela- } \\
\text { bora Norma Técnica de Producción de } \\
\text { Alimentos, producción integrada, eva- } \\
\text { luar los riesgos alimenticios...) } \\
\text { www.elikafundazioa.net }\end{array}$ \\
\hline
\end{tabular}




\begin{tabular}{|c|c|c|}
\hline Entidad & Promotor & Función - Misión \\
\hline $\begin{array}{l}\text { Neiker } \\
\text { (Instituto Vasco de Investi- } \\
\text { gación y Desarrollo Agra- } \\
\text { rio) }\end{array}$ & $\begin{array}{l}\text { Gobierno Vasco } \\
\text { Dpto. Agricultura y Pesca }\end{array}$ & $\begin{array}{l}\text { El Instituto tiene dos centros en Arkaute } \\
\text { y Derio destinados a la investigación } \\
\text { agraria con objeto de mejorar la produc- } \\
\text { tividad y competitividad del Sector Pri- } \\
\text { mario, desarrollar e introducir nuevas } \\
\text { tecnologías y facilitar las demandas de } \\
\text { la industria transformadora. } \\
\text { www.neiker.net }\end{array}$ \\
\hline $\begin{array}{l}\text { Sociedad Pública Mendi- } \\
\text { koi, S.A. }\end{array}$ & $\begin{array}{l}\text { Gobierno Vasco } \\
\text { Dpto. Agricultura y Pesca }\end{array}$ & $\begin{array}{l}\text { Planificar y desarrollar acciones de For- } \\
\text { mación, Promoción y Desarrollo Rural, } \\
\text { en base a las políticas y estrategias defi- } \\
\text { nidas por el Dpto. de Agricultura y Pesca } \\
\text { del Gobierno Vasco. } \\
\text { —-Formación de profesionales del Sec- } \\
\text { tor Primario y aumento de su compe- } \\
\text { titividad. } \\
\text { - Promoción y Desarrollo Rural con el } \\
\text { objetivo de «fijación e incremento de } \\
\text { la población rural»: creación de em- } \\
\text { pleo, mejora de las infraestructuras } \\
\text { rurales, programa EREIN, Nueva Tec- } \\
\text { nología, Coordinación Comercial. } \\
\text { www.mendikoi.net }\end{array}$ \\
\hline $\begin{array}{l}\text { IKT } \\
\text { Nekazal Ikerketa Teknolo- } \\
\text { gia }\end{array}$ & $\begin{array}{l}\text { Promotor: (1989) } \\
\text { - Gobierno Vasco - Dpto. } \\
\text { Agricultura y Pesca. } \\
\text { - Diputaciones Forales. } \\
\text { - Lorra. } \\
\text { - Lurgintza. } \\
\text { - Aga. }\end{array}$ & $\begin{array}{l}\text { Empresa de Ingeniería y Consultoría y } \\
\text { desarrolla proyectos en relación a los } \\
\text { Departamentos de: } \\
\text { - Sistemas y Tecnología de la Informa- } \\
\text { ción. } \\
\text { - Análisis y Estudios Agropesqueros. } \\
\text { - Medio Natural y Sistema de Informa- } \\
\text { ción Geográfica. } \\
\text { www.ikt.es }\end{array}$ \\
\hline $\begin{array}{l}\text { Fundación AZTI Funda- } \\
\text { zioa }\end{array}$ & $\begin{array}{l}\text { Patronato de la Funda- } \\
\text { ción: (1981) } \\
\text { — Gobierno Vasco } \\
\text { — Empresas del Sector } \\
\text { Pesquero, Alimentario y } \\
\text { Medio Ambiental Ma- } \\
\text { rino. }\end{array}$ & $\begin{array}{l}\text { Fundación comprometida con el desarro- } \\
\text { llo social y económico del Sector Pesque- } \\
\text { ro y Alimentario, así como la protección } \\
\text { del medio ambiente marino y los recur- } \\
\text { sos naturales que Desarrolla y Comercia- } \\
\text { liza, para empresas y administraciones } \\
\text { públicas, sus actividades de Investigación } \\
\text { y Desarrollo Tecnológico a través de } 3 \\
\text { campos de actuación: } \\
\text { - Oceanografía y Medio Ambiente Ma- } \\
\text { rino. } \\
\text { - Recursos Pesqueros. } \\
\text { - Tecnología de Alimentos. } \\
\text { www.azti.es }\end{array}$ \\
\hline
\end{tabular}




\begin{tabular}{|c|c|c|}
\hline Entidad & Promotor & Función - Misión \\
\hline $\begin{array}{l}\text { Aberekin S.A. } \\
\text { (Inseminación) }\end{array}$ & $\begin{array}{l}\text { Gobierno Vasco } 1985 \\
\text { Diputación Foral } \\
\text { Asociaciones Ganaderas }\end{array}$ & $\begin{array}{l}\text { Centro para el desarrollo y aplicación de } \\
\text { técnicas de selección y reproducción } \\
\text { animal. } \\
\text { www.aberekin.com }\end{array}$ \\
\hline Basalan, S.A. & Diputación Foral de Bizkaia & $\begin{array}{l}\text { Sociedad Pública dedicada a la ejecución } \\
\text { de trabajos forestales y conservación de } \\
\text { la naturaleza. }\end{array}$ \\
\hline $\begin{array}{l}\text { Lorra } \\
\text { (Servicios Agrícolas y Ga- } \\
\text { naderos) }\end{array}$ & $\begin{array}{l}\text { Cooperativa de } 1 .{ }^{\text {er }} \text { grado } \\
\text { y asociada: } 1986 \\
\text { - Asociaciones de pro- } \\
\text { ductores agrícolas y/o } \\
\text { ganaderos. } \\
\text { - Cooperativa Agraria. } \\
\text { - Entidad Colaboradora: } \\
\text { Caja Rural Vasca - Ipar } \\
\text { Kutxa } \\
\text { (Aglutina a } 4000 \text { produc- } \\
\text { tores de Bizkaia) }\end{array}$ & $\begin{array}{l}\text { Soporte para el mejor desarrollo de las ac- } \\
\text { tividades de las Entidades Jurídicas Aso- } \\
\text { ciadas, así como la prestación de distintos } \\
\text { servicios técnicos y económicos a los so- } \\
\text { cios de las entidades asociadas como a } \\
\text { cualquier otro profesional agrario. } \\
\text { www.lorra-cg.net }\end{array}$ \\
\hline $\begin{array}{l}\text { Aga (Araba), Enhe Zerbi- } \\
\text { tsuak (Bizkaia), Ehnelur } \\
\text { (Gipuzkoa) }\end{array}$ & Sindicato Agrario Ehne & $\begin{array}{l}\text { Empresa que presta servicios de tipo Jurí- } \\
\text { dico, Fiscal, Seguros, Proyectos, Topogra- } \\
\text { fía, Cursos, Gestión Técnico-Económica... } \\
\text { www.enhe.org }\end{array}$ \\
\hline $\begin{array}{l}\text { Lurgintza } \\
\text { Sergal }\end{array}$ & & Apoyo asociaciones. \\
\hline Basoekin, S.I. & $\begin{array}{l}\text { Confederación de Foresta- } \\
\text { listas del País Vasco (2002) }\end{array}$ & Gestión de fincas forestales. \\
\hline
\end{tabular}

\section{B.3. Financiación Ajena a Largo Plazo}

\section{B.3.1. Financiación Garantizada por Sociedades de Garantía Recíproca (S.G.R.)}

La Sociedades de Garantía Recíproca otorgan garantías personales, por aval u otros medios en favor de sus socios y para las operaciones que éstos realicen dentro del tráfico de sus empresas y complementado con asesoría financiera.

Este tipo de sociedades vienen a cubrir una necesidad, fundamentalmente en las PYMES, de mejora de las estructuras y de las condiciones financieras a la que puedan acudir estas empresas, de forma que puedan obtener una financiación a largo plazo y en condiciones financieramente competitivas, pues de otra manera les podría resultar difícil 
obtener, por falta de garantía que aportar a la entidad financiera por los riesgos a largo plazo y mayor volatilidad de una PYME que se asumirían.

La Caja participa como Socio Protector en la entidad OINARRI, Sociedad de Garantía para la Economía Social, S.G.R., y que como el propio nombre indica tienen un origen y acción preferente, aunque no exclusivo, hacia las empresas de Economía Social (Cooperativas, S.A.L...) (www.oinarri.es)

Oinarri tiene otorgado el $91 \%$ de sus avales al 31.12.2001 a financiar Activos Fijos y cuenta con un reafianzamiento de sus riesgos del $75 \%$ en virtud del Convenio, suscrito con el Gobierno Vasco, de reafinanzamiento complementario respecto al de CERSA (Compañía Española de Reafianzamiento), por la que en consecuencia asume el riesgo del $25 \%$ de las garantías otorgadas en sus operaciones.

\section{Participación Sectorial}

\begin{tabular}{|l|c|r|r|r|r|r|}
\hline \multirow{2}{*}{} & \multicolumn{2}{|c|}{$\begin{array}{c}\text { De los Socios } \\
\text { Partícipes (2001) }\end{array}$} & \multicolumn{2}{c|}{$\begin{array}{c}\text { Avales } \\
\text { Formalizados 2001 }\end{array}$} & \multicolumn{2}{c|}{$\begin{array}{c}\text { Acumulado } \\
31.12 .2001\end{array}$} \\
\cline { 2 - 7 } & \multicolumn{1}{|c}{ N. $^{\circ}$} & $\%$ & Importe & $\%$ & Importe & $\%$ \\
\hline Agrícola-Ganadero & 398 & $39,9 \%$ & 244 & $10,7 \%$ & 1.004 & $14,1 \%$ \\
Industria & 279 & $28 \%$ & 953 & $41,7 \%$ & 2.848 & $40 \%$ \\
Servicios & 178 & $17,8 \%$ & 762 & $33,4 \%$ & 2.083 & $29,3 \%$ \\
Transporte & 103 & $10,3 \%$ & 112 & $4,9 \%$ & 626 & $8,8 \%$ \\
Construcción & 40 & $4 \%$ & 213 & $9,3 \%$ & 557 & $7,8 \%$ \\
\hline Total & 998 & $100 \%$ & 2.284 & $100 \%$ & 7.118 & $100 \%$ \\
\hline
\end{tabular}

Como observamos, los socios del Sector Primario representan el $40 \%$ del total pero sólo el $14 \%$ de las operaciones vivas, por lo que tiene una demanda de menor importe unitario.

\section{Condiciones}

\begin{tabular}{|l|l|}
\cline { 2 - 2 } \multicolumn{1}{c|}{} & Avales Financieros \\
\hline Tipo Interés & Euribor $+0,25$ \\
\hline Plazo Amortización & $\begin{array}{l}\text { Inversión en inmuebles: hasta } 12 \text { años sin carencia } \\
\text { Resto Activos Fijos: hasta } 7 \text { años con } 2 \text { años de carencia }\end{array}$ \\
\hline Comisión Apertura & $0,5 \%$ de una sola vez. \\
\hline Comisión Amortización Anticipada & - \\
\hline
\end{tabular}




\section{B.3.2. El Crédito o Préstamo Hipotecario}

El Crédito o Préstamo Hipotecario es una modalidad de financiación garantizada con una hipoteca, lo cual supone una posición privilegiada en la prelación de créditos, que la entidad prestamista, sólo posterior a los créditos a favor del Estado y a los de las aseguradoras por primas.

La práctica habitual en la financiación hipotecaria es la concesión a tipo de interés variable, y amortización por el método francés (cuotas constantes):

1. Indices de referencia de los tipos de interés:

- Indices basados en la emisión de Cédulas Hipotecarias.

- Indice de la Asociación Hipotecaria de España.

- Indices de Referencia del Mercado Hipotecario (préstamos con garantía hipotecaria a plazo $\geq 3$ años por la vivienda de las entidades de crédito).

— Indices basados en la Deuda Pública entre 3 y 6 años.

-Otros: Interbancario, tipo CECA.

2. Plazo de Amortización Optimo con amortización por cuotas constantes:

Según aumenta el plazo de amortización, la cuota periódica disminuye en importe, pero no directamente, de modo que a partir de un plazo la disminución del importe de la cuota es menor que los intereses que deben pagarse de más por alargar el plazo final de amortización.

Plazo óptimo: 1/Ln $(1+$ i) (inverso del logaritmo neperiano de $1+$ i)

El cuadro siguiente muestra el plazo de amortización óptimo, en n. ${ }^{\circ}$ de años de amortización, según si la liquidación es mensual, trimestral... y según el tipo de interés:

\begin{tabular}{|l|c|c|c|c|c|c|c|c|}
\hline \multirow{2}{*}{ Periodicidad } & \multicolumn{7}{|c|}{ Tipos de interés } \\
\cline { 2 - 9 } & 5 & 6 & 7 & 8 & 9 & 10 & 11 & 12 \\
\hline Mensual & 20,04 & 16,71 & 14,33 & 12,54 & 11,15 & 10,04 & 9,13 & 8,37 \\
Trimestral & 20,12 & 16,79 & 14,41 & 12,62 & 11,24 & 10,12 & 9,22 & 8,46 \\
Cuatrimestral & 20,17 & 16,83 & 14,45 & 12,67 & 11,28 & 10,17 & 9,26 & 8,50 \\
Semestral & 20,25 & 16,92 & 14,53 & 12,75 & 11,36 & 10,25 & 9,34 & 8,58 \\
Anual & 20,50 & 17,16 & 14,78 & 12,99 & 11,60 & 10,49 & 9,58 & 8,82 \\
\hline
\end{tabular}


Respecto al Sector Agrario, el aspecto diferenciador sería el de las favorables condiciones aplicables en los préstamos tanto con Garantía Hipotecaria como Personal para se pueden acoger al Convenio de Colaboración Diputación Foral - Entidades Financieras que posibilita la línea de financiación de las inversiones del «Plan de Ayudas al Sector Agrario y Forestal».

-Diputación Foral Araba:

- Cuantía Préstamo: la Diputación señala el importe máximo del préstamo subvencionable.

- Tipo de Interés:

\begin{tabular}{|l|l|l|l|}
\cline { 2 - 4 } \multicolumn{2}{|c|}{} & \multicolumn{1}{|c|}{ Tipo Fijo } & Tipo Variable \\
\hline \multirow{2}{*}{ Préstamo duración $\leq 6$ años } & $\begin{array}{l}\text { Deuda Pública (2-6 años } \\
\text { en secundario) }+1\end{array}$ & Euribor 1 año + 1 \\
\hline \multirow{2}{*}{ Préstamo duración $>6$ años } & 6 Primeros años: & $\begin{array}{l}\text { Deuda Pública (2-6 años } \\
\text { en secundario) }+1\end{array}$ & Variable \\
\cline { 2 - 4 } & Resto: & $\begin{array}{l}\text { Deuda Pública (2-6 años } \\
\text { en secundario) }+1\end{array}$ & Euribor 1 año + 1 \\
\hline
\end{tabular}

* Sobre estos tipos, el prestatario descontará para su pago los puntos de interés subvencionados por la Diputación.

- Carencia máxima: 3 años.

- Plazo Amortización máximo: s/ Diputación con máximo de 15 años.

- Comisión Apertura máxima: 0,5\%.

- Comisión Cancelación: -

- Diputación Foral Bizkaia:

- Cuantía Préstamo: la Diputación señala el importe máximo del préstamo subvencionable.

- Tipo de Interés:

\begin{tabular}{|c|c|c|}
\hline & Tipo Fijo & Tipo Variable \\
\hline Préstamo duración $\leq 10$ años & $7 \%$ & $\begin{array}{l}\text { 1. }{ }^{\text {er }} \text { año: } 5 \% \\
\text { Resto: Mibor } 1 \text { año + 0,75 puntos }\end{array}$ \\
\hline Préstamo duración > 10 años & - & $\begin{array}{l}\text { 1.er año: } 5 \% \\
\text { Resto: Mibor } 1 \text { año + 0,75 puntos. }\end{array}$ \\
\hline
\end{tabular}

* Sobre estos tipos, el prestatario descontará para su pago los puntos de interés subvencionados por la Diputación. 
- Plazo Amortización máximo: s/ Diputación con máximo de 15 años.

- Comisión Apertura máxima: 0,5\%.

- Comisión Cancelación: -

Tanto con la Diputación Foral de Bizkaia como de Araba, entrega la subvención correspondiente a cada préstamo, de una sola vez, en el momento del abono. Para ello actualiza, al tipo de interés del Convenio, las entregas que debe efectuar a lo largo de la vida del préstamo, al momento inicial.

- Gobierno Vasco:

- Cuantía Préstamo: El Departamento de Agricultura y Pesca determina la cuantía máxima de inversión subvencionable.

- Tipo de Interés:

\begin{tabular}{|l|l|l|}
\cline { 2 - 3 } \multicolumn{1}{c|}{} & Tipo Fijo & \multicolumn{1}{c|}{ Tipo Variable } \\
\hline Préstamo duración $\leq 7$ años & $6,75 \%$ & Euribor $+0,75$ puntos \\
\hline Préstamo duración $>7$ años & $7,50 \%$ & Euribor +1 punto \\
\hline
\end{tabular}

* En préstamos avalados por una S.G. Recíproca, el tipo de interés se reduce en 0,25 puntos.

- Carencia máxima: 2 años.

- Plazo Amortización máximo: s/ Resolución de la Dirección de Política e Industria Agroalimentaria.

- Comisión Apertura máxima: 0,5\%.

El importe de la subvención se aplicará a la amortización del principal de la operación de préstamo y será calculado financieramente, siendo equivalente a la suma de los valores actuales de las subvenciones de intereses a pagar en cada vencimiento, utilizando como tasa de actualización el tipo de interés inicial de la operación.

\section{B.3.3. LEASING}

Es un sistema de financiación por el cual la empresa de Leasing, previa compra al proveedor acordado, cede a su cliente (arrendatario), el uso de un bien determinado, a cambio de una retribución periódica durante un plazo de tiempo, estableciéndose un derecho de opción de compra del arrendatario sobre dicho bien a partir de una fecha determinada. 
El bien objeto de Leasing puede ser un bien de equipo (incluidos equipos informáticos), vehículos, y otros elementos de transporte, bienes de consumo duradero, o bienes inmuebles.

\section{B.3.4. CRÉditos Sindicados}

Las operaciones de crédito o préstamo en las que participan, no una, sino diversas entidades de crédito como prestamistas, debido a la elevada cuantía de la financiación o a otras circunstancias especiales, lo cual permite a la entidad financiera reducir el riesgo y poder acceder a operaciones a las cuales no se podría acceder por insuficiente envergadura.

Nuestras operaciones en esta forma de financiación son limitadas, al reducirse el negocio inducido, al ser varias las entidades financieras participantes.

\section{B.3.5. Mercados Financieros}

En los últimos años se está acentuando el proceso de «desintermediación» mediante el proceso de «emisión de activos financieros» directamente por la empresa destinados a los agentes últimos (ahorradores) sin ningún proceso de intermediación (actividad tradicional realizada por las entidades financieras).

Los títulos emitidos pueden ser a largo plazo (Bonos, Obligaciones...) o a corto plazo (Pagarés de empresa) y se requiere la cumplimentación de un «folleto de emisión» y los trámites correspondientes ante la CNMV.

Pero estos emisores de deudas en PYMES sin Rating, se enfrentan por tanto al problema del «Riesgo» y consiguiente encarecimiento de esta fórmula de financiación.

Existen recursos híbridos entre recursos propios y recursos ajenos como los «Títulos Convertibles» que son títulos de renta fija que llevan aparejada la posibilidad de canjearse por acciones.

\section{B.4. Financiación Ajena a Corto Plazo}

\section{B.4.1. Descuento de Efectos}

Mediante esta financiación, la entidad de crédito adelanta al cliente el importe de unos derechos de cobro futuros, los cuales se han 
instrumentado en un documento justificativo de los mismos (letra de cambio, pagaré...) descontando de aquel importe los intereses y gastos pactados y los impuestos devengados. El descuento de efectos supone el adelanto del cobro de su importe y consiguiente asunción de gestión de cobro, pero no se responsabiliza del buen fin de los mismos, de forma que en caso de impago procederá a cargarla en cuenta junto a las comisiones y gastos suplidos correspondientes.

El coste efectivo o real del descuento depende de:

a) Tipo de Interés Nominal y Comisión de Cobro:

— Hay dos modalidades básicas de liquidación:

I) «Forfait» en el que el tipo de interés aplicado lleva un componente intrínseco de comisión por el servicio de cobro.

II) «No Forfait» en el que se aplican tanto el interés como la comisión de forma separada.

—Normalmente se cobran siempre un mínimo de hasta 15 días de intereses, aun cuando el vencimiento del efecto sea menor de dicho mínimo.

b) Timbres o impuestos de actos jurídicos documentados y transmisiones patrimoniales. En caso de la modalidad de «Anticipo de Créditos» este pago está exento.

c) Gastos suplidos.

La decisión de descontar una remesa de efectos o la simple cesión al cobro de las mismas, desde el punto de vista de coste implica además del cálculo de los anteriores costes, estudiar los siguientes aspectos:

d) Aplicación de diferente fecha-valor del ingreso (1 día menos en el descuento).

e) Saldos positivos mantenidos en cuenta con motivo del descuento y remunerados a tipo efectivo inferior al mismo.

\section{B.4.2. Póliza o Cuenta de CRédito a la vista}

La Póliza o Cuenta de Crédito a la vista es un contrato de crédito instrumentado en forma de cuenta corriente bancaria, permitiendo la disposición de saldos deudores hasta un límite determinado y hasta una fecha de vencimiento, a partir de la cual, o bien se devuelve la cantidad dispuesta en esa fecha, o bien se renueva la póliza. 
Diferencias entre préstamos y crédito

\begin{tabular}{|c|c|}
\hline Préstamo & Crédito \\
\hline $\begin{array}{l}\text { Contrato real, se perfecciona con la } \\
\text { entrega del dinero. }\end{array}$ & $\begin{array}{l}\text { Contrato consensual, se perfecciona } \\
\text { con el consentimiento. }\end{array}$ \\
\hline $\begin{array}{l}\text { Contrato unilateral, sólo produce obli- } \\
\text { gaciones para el prestatario: devolver } \\
\text { el capital, abonar los intereses, etc. }\end{array}$ & $\begin{array}{l}\text { Contrato bilateral, genera obligacio- } \\
\text { nes para ambas partes. }\end{array}$ \\
\hline $\begin{array}{l}\text { La entidad financiera entrega al pres- } \\
\text { tatario una cantidad de dinero. }\end{array}$ & $\begin{array}{l}\text { La entidad financiera se compromete } \\
\text { a poner a disposición del acreditado } \\
\text { dinero hasta un límite pactado y du- } \\
\text { rante un periodo de tiempo prefijado. }\end{array}$ \\
\hline $\begin{array}{l}\text { El prestatario se obliga a restituir la } \\
\text { suma prestada, más los intereses, al } \\
\text { finalizar un plazo establecido. }\end{array}$ & $\begin{array}{l}\text { El acreditado puede disponer de los } \\
\text { fondos dentro del plazo y límites fija- } \\
\text { do, realizando disposiciones totales o } \\
\text { parciales que se irán reflejando en la } \\
\text { cuenta de crédito. }\end{array}$ \\
\hline $\begin{array}{l}\text { El prestatario sólo reduce su deuda } \\
\text { con las amortizaciones en los plazos } \\
\text { fijados. Estas amortizaciones son de- } \\
\text { voluciones parciales de la suma pres- } \\
\text { tada y sólo se amortiza totalmente al } \\
\text { cancelar el préstamo. }\end{array}$ & $\begin{array}{l}\text { El acreditado puede hacer devolucio- } \\
\text { nes, totales o parciales, de las cantida- } \\
\text { des dispuestas, que se irán reflejando } \\
\text { en la cuenta de crédito, pudiendo in- } \\
\text { cluso superar el volumen de los ingre- } \\
\text { sos al de las disposiciones. }\end{array}$ \\
\hline $\begin{array}{l}\text { Los intereses se abonan por la totali- } \\
\text { dad del capital pendiente. }\end{array}$ & $\begin{array}{l}\text { Los intereses se abonan en función } \\
\text { del capital dispuesto. }\end{array}$ \\
\hline $\begin{array}{l}\text { Las amortizaciones, que se ajusta al } \\
\text { cuadro de amortización incluido en la } \\
\text { póliza o escritura, suponen una devo- } \\
\text { lución parcial del capital recibido. }\end{array}$ & $\begin{array}{l}\text { El capital dispuesto deberá devolver- } \\
\text { se al vencimiento o en las bajas o re- } \\
\text { ducciones de límites estipuladas. }\end{array}$ \\
\hline
\end{tabular}

A efectos de calcular el coste efectivo, además del tipo de interés depende de dos conceptos relacionados con el uso medio del límite establecido en la póliza de crédito:

a) Comisión de apertura: pagadera una sola vez al inicio de la vida de la cuenta de crédito y no aplicable en los contratos con renovaciones automáticas.

b) Comisión de disponibilidad o de «no uso»: pagadera junto a la liquidación de intereses y es un porcentaje sobre la disponibilidad media no usada de la póliza de crédito en cada periodo de liquidación. 
Según el uso realizado de la póliza, el coste final de la misma será distinto. A medida que disminuye el uso de la póliza, el importe de las comisiones es mayor, y al revés con lo que es importante analizar el uso a realizar de la póliza.

Gráfico con dichos efectos:

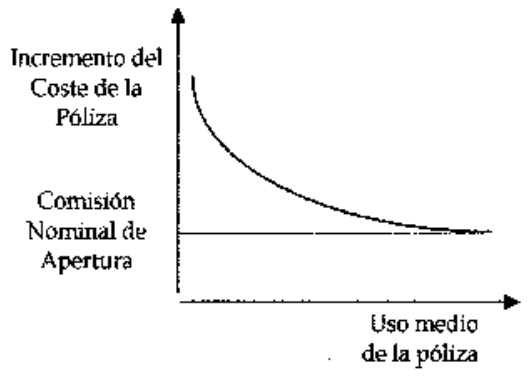

Comisión Apertura

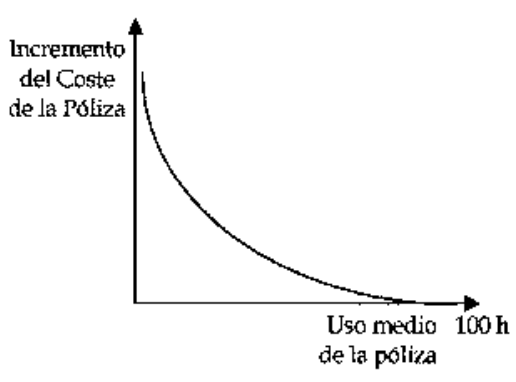

Comisión Disponibilidad

Finalmente, si es importante resaltar que la póliza o cuenta de crédito a la vista, no es sólo una forma de financiación, sino también una forma de gestionar la posición de tesorería.

Este es un instrumento de financiación usual en la Caja con las Cooperativas Agrícolas, fundamentalmente de Alava, utilizado con una doble finalidad: la primera y fundamentalmente por el que se canaliza en las cuentas de los agricultores cooperativistas los pagos que han de realizar las Cooperativas a sus socios por los productos entregados: cereales, patatas y uva. Las campañas son anuales, para algunas Cooperativas de enero a diciembre y otras de julio a junio. Además también se utiliza como un instrumento de financiación indirecta a los socios de las cooperativas por las compras que éstos le hacen de productos como «Fitosanitarios» de forma que, el socio no paga a la cooperativa en el momento del suministro, financiando la compra que la cooperativa tenga que realizar a terceros. Las compañías van desde la fecha de generación (marzo a julio) hasta el término de la compañía (septiembre / octubre).

Normalmente son pólizas con renovación pactada, sin comisiones de apertura y disponibilidad y financiadas con ayudas de la propia Caja dado el negocio indirecto con todos los socios de la Cooperativa. 
Nota: La decisión de cuál es el instrumento óptimo o porcentajes óptimos de los instrumentos de financiación ajena a corto plazo, es preciso analizar además del costo efectivo de una u otra fórmula, aspectos menos cuantificables como los costes de gestión que supone cada fórmula de financiación, cartera de efectos insuficiente, flexibilidad para cubrir una necesidad financiera difícil...

\section{B.4.3. OtRAS FORMAS DE FINANCIACIÓN A CORTO PLAZO}

\section{B.4.3.1. Anticipos de Crédito}

La entidad financiera anticipa el importe de los créditos que la empresa tiene sobre sus clientes o deudores, y cuyo cobro se instrumenta normalmente mediante recibo.

Es una figura similar a la del descuento de efectos, pero sin existir un título físico o efecto que representa los derechos de cobro individuales sobre cada cliente. La comunicación de la empresa a la entidad de crédito es mediante conexión informática (CSB N. ${ }^{\circ}$ 58) sin aportar facturas ni recibos y por tanto se evita el coste de los timbres, aunque por el contrario no hay "ejecutividad» en dichos créditos, siendo por tanto un procedimiento aconsejable ante créditos con garantía para la empresa.

\section{B.4.3.2. Factoring}

Es una «cesión de crédito» entre un cliente y una firma especializada en operaciones de este tipo regulado en el art. 347 del Código de Comercio por el que se transfiere el crédito mercantil, con información al deudor, y tiene las siguientes características:

- Cobertura de Riesgo de Crédito al 100 \% de la deuda (En «Factoring con recurso» no existe).

- Gestión de Cobro y Administración.

-Financiación hasta el 80-85 \% de las deudas (el resto engrosa la cuenta de reservas, que se va transmitiendo al cliente según se cobran las deudas) (En «Factoring sin financiación» no existe).

La financiación no está en función de la solvencia de la empresa, sino de los clientes.

El Factoring de exportaciones es una alternativa a los cobros de exportación mediante «Crédito Documentario» donde es el cliente 
quien inicia las gestiones para pactar y abrir el Crédito Documentario a favor del exportador.

En este apartado se puede comentar una figura jurídica de carácter específico para la explotación conjunta de activos en el sector agrario como son las «CUMA»: Cooperativas de Utilización de Maquinaria Agrícola, que con cooperativas específicas que agrupan a diversos agricultores con el objeto de compra y utilización conjunta de maquinaria agrícola como "Cosechadoras» de remolacha, patatas, cereal... y que para su financiación utiliza préstamos a medio plazo, y que dada la adquisición, en ciertos casos, de maquinaria de importación utiliza por ejemplo los Créditos Documentarios como instrumento de Garantía de Pago, que otorga la entidad financiera del importador (la (UMA) a la entidad financiera del exportador y pueden realizar la compra-venta con los requisitos y exigencias pactadas entre ellos.

\section{B.4.3.3. El Confirming}

Es una operación conjunta de «financiación al proveedor» de una operación y de la gestión de pagos del cliente, por el cual el cliente informa a su entidad financiera de las facturas de proveedores que ha conformado, y que consecuentemente pagará a su vencimiento. La entidad, a su vez, lo comunica al proveedor, el cual recibirá al vencimiento un cheque emitido por dicha entidad.

A partir de ese momento, la entidad puede actuar financiando tanto al deudor o pagador (a través de una póliza de crédito, por ejemplo, donde se cargan los cheques a su vencimiento) como al proveedor o acreedor (a través de un descuento de la factura, por ejemplo, que se le debe abonar).

La actuación de «Compra» a proveedores es fundamental para mejorar el ciclo financiero de forma que genere recursos aplicables a diferentes finalidades (reducción de financiación bancaria, inversión de activos financieros...), para lo cual, entre otros es importante conseguir que los proveedores aporten la máxima financiación neta para las compras.

\section{B.4.3.4. Renting}

Es un sistema de financiación por el cual se permite el uso de bienes por plazo variable, mediante el pago de una tasa, siendo además por cuenta del propietario la «conservación» del objeto alquilado, pu- 
diendo proporcionar en ciertos casos los medios humanos necesarios para la explotación, cuyos gastos están normalmente incluidos en la tasa de alquiler.

Es, por tanto, una figura similar al «leasing» que anteriormente hemos comentado, pero centrado en bienes de equipo y a corto plazo, y que además del arrendamiento puro se incluye en la tasa periódica el coste de diversos servicios de mantenimiento, conservación y seguros del bien por cuenta del propietario.

\section{B.4.3.5. Circulante Operativo}

Así mismo, podrá utilizar fuentes de carácter «Circulante Operativo» como es el acortamiento del periodo de cobro a clientes, alejamiento del periodo de pago a proveedores, negociación para el aplazamiento de diversos pagos... 